Disorders of the Nervous System

\title{
A Functionally Defined In Vivo Astrocyte Population Identified by c-Fos Activation in a Mouse Model of Multiple Sclerosis Modulated by S1P Signaling: Immediate-Early Astrocytes (ieAstrocytes)
}

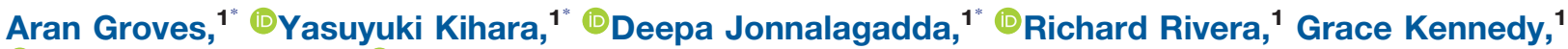
(1) Mark Mayford, ${ }^{2}$ and (1)Jerold Chun ${ }^{1}$

https://doi.org/10.1523/ENEURO.0239-18.2018

${ }^{1}$ Sanford Burnham Prebys Medical Discovery Institute, La Jolla, CA 92037 and ${ }^{2}$ Department of Psychiatry, University of California San Diego, La Jolla, CA 92037

\section{Visual Abstract}

\section{$\mathrm{EAE} \rightarrow \mid \mathbf{s} 1 \mathrm{P}$}
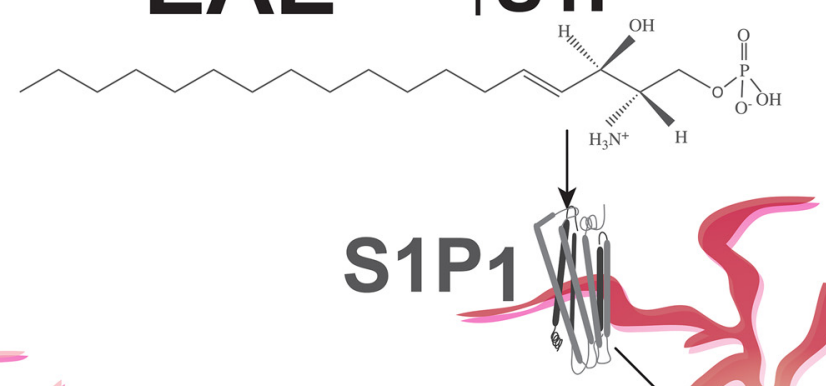

FTY720-P

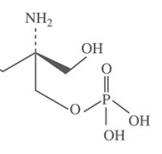

s1P.
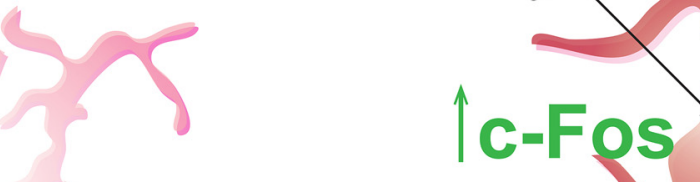

GFAP ${ }^{+}$
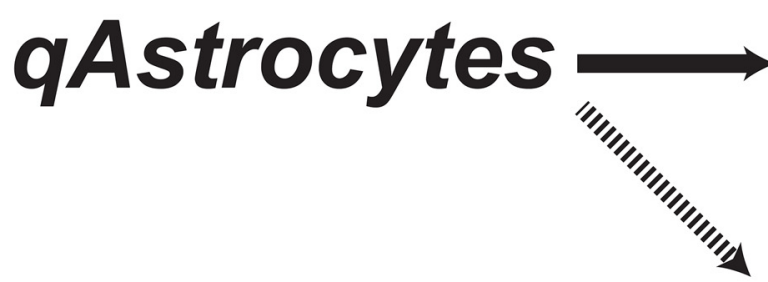

म๑)

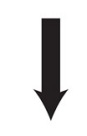

Reactive Astrocytes 


\section{Significance Statement}

A new, functionally defined in vivo subpopulation of astrocytes termed immediate-early astrocytes (ieAstrocytes) was identified as the first and predominant CNS cell type showing c-Fos activation, in an animal model of multiple sclerosis (MS). ieAstrocytes track with disease severity. The approved MS drug fingolimod (FTY720, an S1P receptor modulator) reduced ieAstrocyte formation as well as clinical disease. Agents that prevent or reduce ieAstrocytes could represent a new strategic target for treating MS and other neuroinflammatory and neurodegenerative brain disorders.

Astrocytes have prominent roles in central nervous system (CNS) function and disease, with subpopulations defined primarily by morphologies and molecular markers often determined in cell culture. Here, we identify an in vivo astrocyte subpopulation termed immediate-early astrocytes (ieAstrocytes) that is defined by functional c-Fos activation during CNS disease development. An unbiased screen for CNS cells showing c-Fos activation during experimental autoimmune encephalomyelitis (EAE), a mouse model for multiple sclerosis (MS), was developed by using inducible, TetTag c-Fos reporter mice that label activated cells with a temporally stable, nuclear green fluorescent protein (GFP). Four-dimensional (3D over time) c-Fos activation maps in the spinal cord were produced by combining tissue clearing (iDISCO) and confocal microscopy that identified onset and expansion of $\mathrm{GFP}^{+}$cell populations during EAE. More than $95 \%$ of the $\mathrm{GFP}^{+}$cells showed glial fibrillary acidic protein (GFAP) immunoreactivity -in contrast to absent or rare labeling of neurons, microglia, and infiltrating immune cellswhich constituted ieAstrocytes that linearly increased in number with progression of EAE. ieAstrocyte formation was reduced by either astrocyte-specific genetic removal of sphingosine 1-phosphate receptor $1\left(\mathrm{~S}_{1} \mathrm{P}_{1}\right)$ or pharmacological inhibition by fingolimod (FTY720), an FDA-approved MS medicine that can functionally antagonize $\mathrm{S}_{1} \mathrm{P}_{1}$. ieAstrocytes thus represent a functionally defined subset of disease-linked astrocytes that are the first and predominant CNS cell population activated during EAE, and that track with disease severity in vivo. Their reduction by a disease-modifying agent supports their therapeutic relevance to MS and potentially other neuroinflammatory and neurodegenerative diseases.

Key words: Astrocyte; c-Fos GPCR; lipid mediator; neuroinflammation; S1P

\section{Introduction}

Neuroinflammation in the central nervous system (CNS), as epitomized by multiple sclerosis (MS), involves

Received June 13, 2018; accepted August 25, 2018; First published September 13, 2018.

J.C. has received honoraria, consulting fees, and grant support from Novartis. All other authors declare no competing financial interests.

Author contributions: J.C. conceived of initial concepts. A.G., Y.K., D.J., R.R., and G.K., performed research; A.G., Y.K., and D.J., analyzed research; M.M. contributed unique mice; and Y.K., D.J., A.G., and J.C. wrote the manuscript.

This work was supported by a grant from NIH DA019674 and NS084398 (J.C.) and Novartis (J.C.), NIH NS103940 (Y.K.) a fellowship from the Uehara Memorial Foundation, the Kanae Foundation for the Promotion of Medical Science, Mochida Memorial Foundation for Medical and Pharmaceutical Research, and the Human Frontier Science Program (Y.K.). A.G was supported by Medical Scientist Training Program and Pharmacology Training Grant at University of California San Diego (T32GM007752).

${ }^{*}$ A.G., Y.K., and D.J. contributed equally to this work.

Acknowledgments: We thank K. Spencer (The Scripps Research Institute) for assistance with microscopy; V. Brinkmann and Novartis for gifts of FTY720 and discussions; L. Boyd (Sanford Burnham Prebys Medical Discovery Institute), J. Wong, H. Mirendil, and all the lab members for discussions; and D. Jones for editorial assistance.

Correspondence should be addressed to Jerold Chun. 10901 N. Torrey Pines Road, La Jolla, CA 92037. E-mail: jchun@sbpdiscovery.org.

https://doi.org/10.1523/ENEURO.0239-18.2018

Copyright (C) 2018 Groves et al.

This is an open-access article distributed under the terms of the Creative Commons Attribution 4.0 International license, which permits unrestricted use, distribution and reproduction in any medium provided that the original work is properly attributed. activation of resident immune-competent cells, including astrocytes (Cekanaviciute and Buckwalter, 2016), along with infiltration of peripheral immune cells (González and Pacheco, 2014), which have been associated with multiple CNS pathologies such as MS (Noseworthy et al., 2000), Alzheimer's disease (Acosta et al., 2017), and neuropsychiatric disorders (Trepanier et al., 2016). MS is a prototypical neuroinflammatory disease that also includes demyelination and neurodegeneration in the CNS (Noseworthy et al., 2000). Its cause is unclear; however, in animal models such as experimental autoimmune encephalomyelitis (EAE), immune cells, particularly CD4 $4^{+} \mathrm{T}$ cells, infiltrate the CNS to initiate demyelination and neurodegeneration. Both EAE and human MS can be therapeutically treated by the FDA-approved medicine fingolimod (FTY720; Herr and Chun, 2007; Chun and Hartung, 2010; Lee et al., 2010; Chun and Brinkmann, 2011; Noguchi and Chun, 2011).

FTY720 is a chemical analog of a naturally occurring lipid, sphingosine. It can be phosphorylated by endogenous sphingosine kinases to produce FTY720-phosphate (FTY720-P), an analog of the bioactive lysophospholipid known as sphingosine 1-phosphate (S1P). S1P signals through five receptor subtypes $\left(\mathrm{S}_{1} \mathrm{P}_{1-5}\right)$, all of which are $\mathrm{G}$ protein-coupled receptors (GPCRs; Kihara et al., 2014) that can have roles in neuroinflammation (Gardell et al., 2006; Herr and Chun, 2007; Moon et al., 2015; Proia and Hla, 2015; Tsai and Han, 2016). FTY720-P also signals 
through S1P receptors, engaging four of the five known subtypes $\left(\mathrm{S}_{1} \mathrm{P}_{1}, \mathrm{~S}_{1} \mathrm{P}_{3}, \mathrm{~S}_{1} \mathrm{P}_{4}\right.$, and $\mathrm{S}_{1} \mathrm{P}_{5}$; Kihara et al., 2015). In particular, $S 1 P_{1}$ is thought to be mechanistically important in MS in that a functional antagonism of $\mathrm{S}_{1} \mathrm{P}_{1}$ reduces lymphocyte egress from secondary lymphoid organs, resulting in a decreased number of pathogenic lymphocytes entering the CNS (Mandala et al., 2002; Arnon et al., 2011). Complementing these immune effects, a direct CNS mechanism of action (MOA) for fingolimod has been implicated (Choi et al., 2011), which also involves functional antagonism of $\mathrm{S}_{1} \mathrm{P}_{1}$ expressed by astrocytes, based on similar results observed following the genetic removal of $\mathrm{S}_{1} \mathrm{P}_{1}$ from astrocytes, which both resulted in reduced EAE severity and elimination of FTY720 efficacy, despite intact lymphocyte trafficking effects (Choi et al., 2011). S1P signaling is also implicated in controlling astrocyte functions that include gap junction formation (Rouach et al., 2006), migration (Mullershausen et al., 2007), cytokine production (Dusaban et al., 2017), and nitric oxide production (Colombo et al., 2014) via $\mathrm{S}_{1} \mathrm{P}_{1}$ and/or $\mathrm{S}_{1} \mathrm{P}_{3}$, all of which support S1P-mediated roles for astrocytes in EAE and MS.

To identify CNS cell types altered during neuroinflammatory processes, we developed an unbiased in vivo screen based on transcription of c-Fos (Bullitt, 1990), an immediate-early gene (IEG) that is rapidly transcribed in response to cellular stimuli, independent of de novo protein synthesis (Lau and Nathans, 1987). c-Fos can be activated in astrocytes (McNaughton and Hunt, 1992; Anderson et al., 1994; Morishita et al., 2011; Yester et al., 2015), microglia (Eun et al., 2004), and oligodendrocytes (Muir and Compston, 1996), as well as within neurons associated with memory (Matsuo et al., 2008). We adapted a conditional c-Fos reporter mouse that historically marks cells with nuclear GFP, which could be followed in four-dimensional (3D over time) analyses. Remarkably, more than $95 \%$ of disease-activated cells in vivo were astrocytes that we named immediate-early astrocytes (ieAstrocytes). Here, we describe the in vivo screen used to identify the ieAstrocytes produced by EAE challenge, including their temporal and spatial patterns and their quantitative modification by S1P receptor signaling, demonstrated through the use of genetic and pharmacological interventions.

\section{Materials and Methods}

\section{Mice}

All animal protocols were approved by the Sanford Burnham Prebys Medical Discovery Institute IACUC and conformed to National Institutes of Health guidelines and public law. The TetTag-cFos mice were generated by crossing Tg(Fos-tTA)1Mmay (MGl:5014071) and Tg(tetOHIST1H2BJ/GFP)47Efu/J (RRID:IMSR_JAX:005104) mice, which expressed a GFP-histone H2B fusion protein (GFP-H2B) under a tetO promoter controlled by a c-Fos inducible tetracycline transactivator (TTA) protein as described earlier (Tayler et al., 2011). S1 $\mathrm{P}_{1}$ flox/flox:hGFAP-cre mice (Choi et al., 2011) were crossed with TetTag mice for multiple generations to generate astrocyte-specific $\mathrm{S}_{1} \mathrm{P}_{1}$ deletion $\left(\mathrm{S}_{1} \mathrm{P}_{1}-\mathrm{AsCKO}^{\text {fos }}\right.$, TetTag:S1P ${ }_{1}^{\text {flox/flox:hGFAP-cre) }}$ and their littermate controls (WT ${ }^{\text {fos }}$, TetTag:S1P ${ }_{1}^{\text {flox/flox }}$ ). TetTag-cFos mice were maintained on doxycycline diet (DOX, $40 \mathrm{mg} / \mathrm{kg}$; Bio-Serv) throughout breeding, birth, and development to prevent GFP-H2B expression until experimental examination.

\section{EAE}

EAE was induced in 7- to 13-wk-old female mice (Kihara et al., 2009). Briefly, mice were immunized subcutaneously with $150 \mu \mathrm{g}$ myelin oligodendrocyte glycoprotein 35-55 $\left(\mathrm{MOG}_{35-55}\right)$ (MEVGWYRSPFSRVVHLYRNGK, EZBiolab) in PBS and complete Freund's adjuvant containing $4 \mathrm{mg} / \mathrm{mL} \mathrm{M}$. Tuberculosis H37Ra (Difco) with or without intraperitoneal injection of $250 \mathrm{ng}$ pertussis toxin (List Biological Laboratories) on days 0 and 2. Daily clinical scores corresponding to the most severe sign observed were given as follows: 0 , no sign; 0.5 , mild loss of tail tone; 1.0, complete loss of tail tone; 1.5 , mildly impaired righting reflex; 2.0, abnormal gait and/or impaired righting reflex; 2.5 , hindlimb paresis; 3.0 , hindlimb paralysis; 3.5, hindlimb paralysis with hind body paresis; 4.0, hind- and forelimb paralysis; and 4.5 , death or severity necessitating euthanasia. FTY720 was administered via gavage ( $1 \mathrm{mg} / \mathrm{kg}$; Novartis).

\section{Histologic analyses (cryosectioning)}

Mice were euthanized with an overdose of isoflurane followed by rapid dissection of spinal cords (SCs). SCs were cut in three sections, embedded in Tissue-Tek Optimal Cutting Temperature (OCT; Ted Pella) compound, and frozen on crushed dry ice. Cryostat sections (16 $\mu \mathrm{m})$ were collected on Superfrost Plus microscope slides (Thermo Fisher Scientific) and fixed (10 min) with freshly prepared $4 \%$ paraformaldehyde (PFA; Sigma) in PBS. Sections were washed three times in TBS with $0.3 \mathrm{M}$ glycine, permeabilized with $0.1 \%$ Triton X-100 in TBS, blocked with species-appropriate serum, and immunolabeled with chicken anti-GFAP (1:1000 dilution, Neuromics, Cat \#CH22102, RRID:AB_10014322), rabbit antiNeuN (1:400 dilution, Millipore, Cat \#MABN140, Clone \#27-4, RRID:AB_2571567), mouse anti-Olig1,2,3 (1:100 dilution, Neuromics, Cat \#MO15059, Clone \#257224, RRID: AB_1620409), rabbit anti-lba1 (1:500 dilution, Wako, Cat \#019-19741, Clone \#NCNP24, RRID:AB_839504), and hamster anti-CD3e (1:500 dilution, BD Biosciences, Cat\# 553057, Clone \#145-2C11, RRID:AB_394590). Antigen retrieval with Diva Decloaker (Biocare) as per manufacturer's instructions was performed in place of permeabilization for Olig1,2,3 staining. Sections were washed in PBS, labeled with secondary antibodies conjugated with Alexa Fluor 568 (1:2000 dilution, Thermo Fisher Scientific; Cat\# A-11041, RRID:AB_2534098; Cat\# A-11031, RRID:AB_144696; Cat\# A-11036, RRID:AB_10563566) or DyLight 649 (1:2000 dilution, BioLegend, Cat\# 405505, RRID:AB_1575122), counterstained with DAPI (1:10,000 dilution, Thermo Fisher Scientific, Cat\# D1306, RRID:AB_2629482), and coverslipped with Vectashield Antifade Mounting Medium (Vector). Sections were visualized and images acquired on a Zeiss Imager 1D microscope (Axiovision 4.8, RRID:SCR_002677), a Zeiss ApoTome.2 (Zen 2 Blue Edition, RRID:SCR_013672), or a Nikon $\mathrm{A}^{+}{ }^{+}$(NIS-Elements v4.4, RRID:SCR_014329). 
a

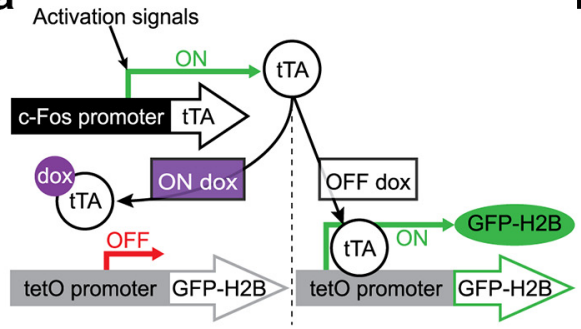

DAPI
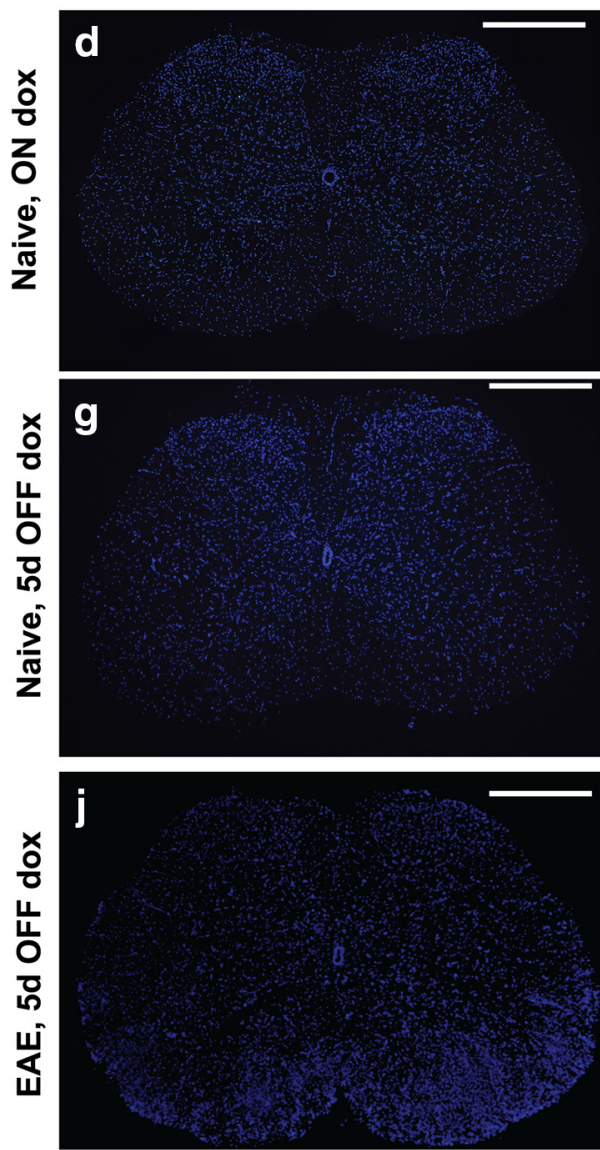

b

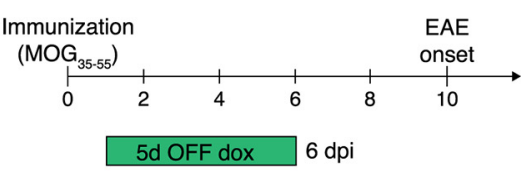

$5 \mathrm{~d}$ OFF dox $8 \mathrm{dpi}$

$5 d$ OFF dox

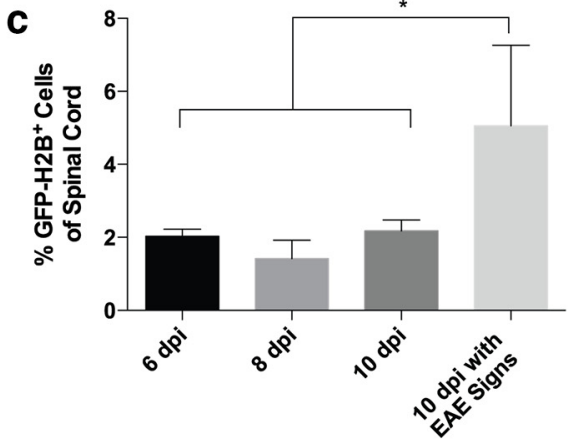

DAPI/GFP-H2B
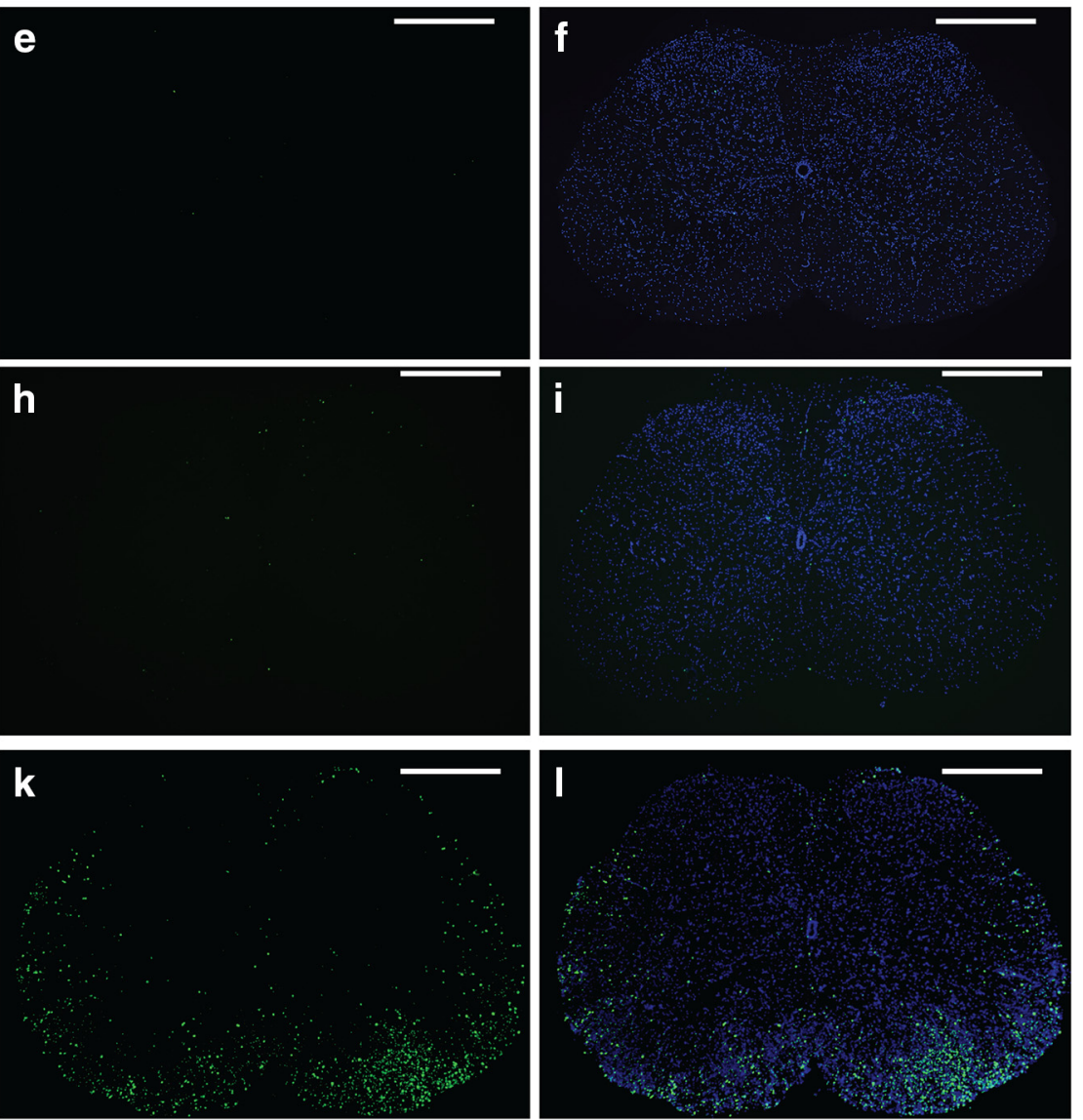

Figure 1. c-Fos reporter mice display increased c-Fos activation in EAE spinal cords (SCs). a, Schematic representation of doxycycline (dox)-controlled GFP-H2B expression. Dox removal (off dox) allows tTA (tetracycline-transactivator) expression under a c-Fos promoter to drive fused green fluorescent protein-human histone H2B (GFP-H2B) expression. $\boldsymbol{b}$, Experimental scheme of 5-d dox removal period. Average onset of EAE in $\mathrm{WT}^{\text {fos }}$ controls was $10.6 \pm 1.07$ days postimmunization (dpi; $n=7$ ). $\boldsymbol{c}$, GFP-H2B ${ }^{+}$ population in the spinal cord was determined by FCM $(n=4$ animals, mean \pm SEM, $* p<0.05$, one-way ANOVA with Bonferroni's post hoc test). $\boldsymbol{d}-\boldsymbol{l}$, Representative spinal cord coronal sections. In the naive SC, DOX inhibited extra-experimental tagging of GFP ${ }^{+}$ cells. Virtually no GFP-H2B was observed $(\boldsymbol{d}-\boldsymbol{f})$. On DOX removal, there were sparse and dispersed $\mathrm{GFP}^{+}$cells in the naive SC over $5 \mathrm{~d}(\boldsymbol{g}-\boldsymbol{i})$. EAE induced robust GFP signals in the SC at 5 days post-onset (dpo) that were clustered in lesions and along the periphery (j-l). Scale bar, $500 \mu \mathrm{m}$.

\section{Histologic analyses (iDISCO)}

Immunolabeling-enabled three-dimensional imaging of solvent-cleared organs (iDISCO) was employed to visualize GFP-H2B in intact SCs (Renier et al., 2014). Mice were euthanized with an overdose of isoflurane anesthesia, then fixed by intracardiac perfusion of PBS followed by 4\% PFA in PBS. SCs were dissected out and postfixed overnight in 4\% PFA in PBS; washed in PBS, 50\% methanol in PBS, $80 \%$ methanol in PBS, and $100 \%$ methanol; and bleached in $20 \%$ DMSO in methanol containing $5 \%$ $\mathrm{H}_{2} \mathrm{O}_{2}$ at $4^{\circ} \mathrm{C}$. Samples were washed again in $100 \%$ methanol, 20\% DMSO in methanol, $80 \%$ methanol in PBS, $50 \%$ methanol in PBS, PBS, and PBS containing $0.2 \%$ Triton $\mathrm{X}-100$ and incubated at $37^{\circ} \mathrm{C}$ in PBS containing 
Naive mouse

5 days OFF dox
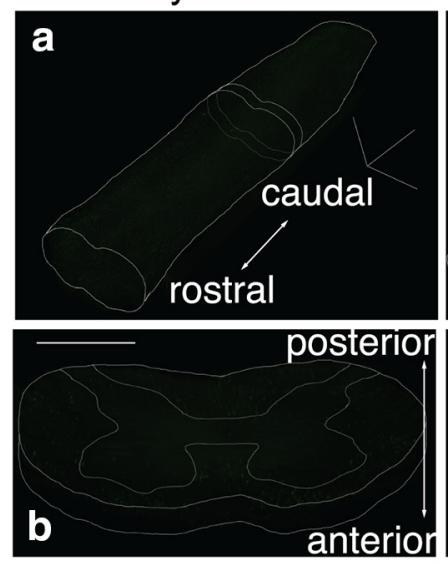

EAE 1-dpo

1 day OFF dox
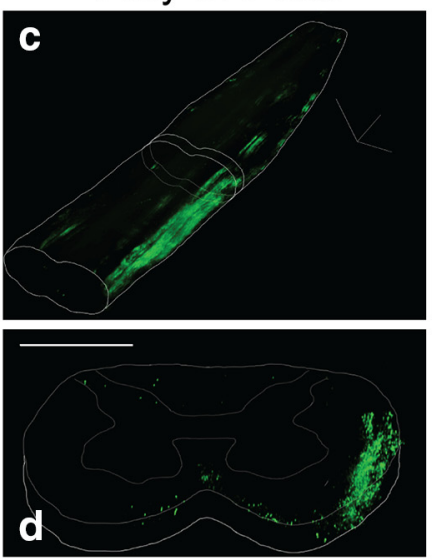

EAE 3-dpo

3 days OFF dox
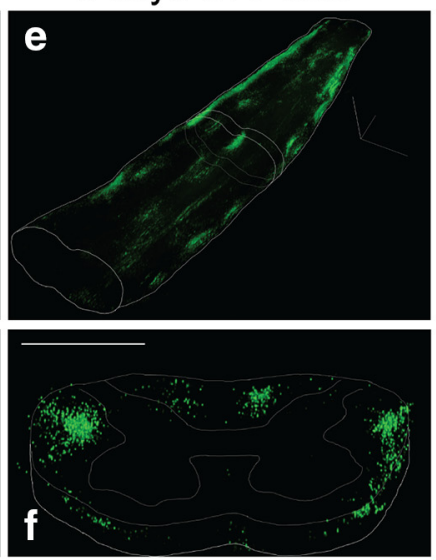

EAE 5-dpo

5 days OFF dox
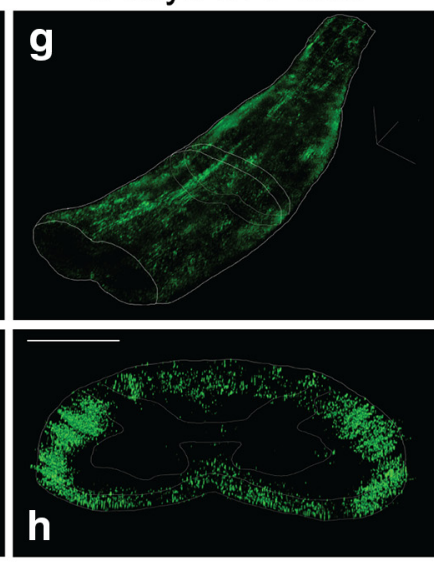

i

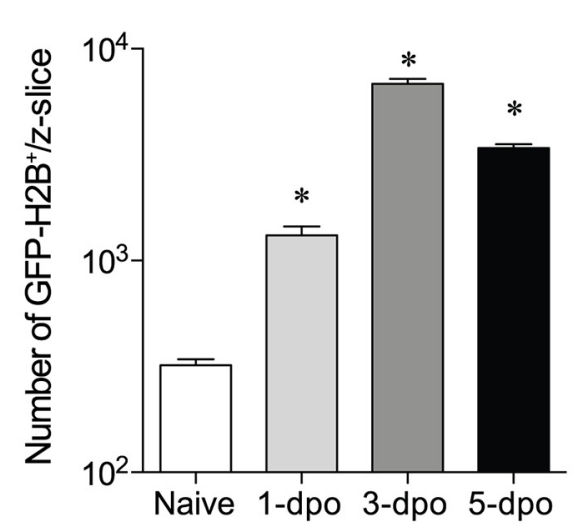

j

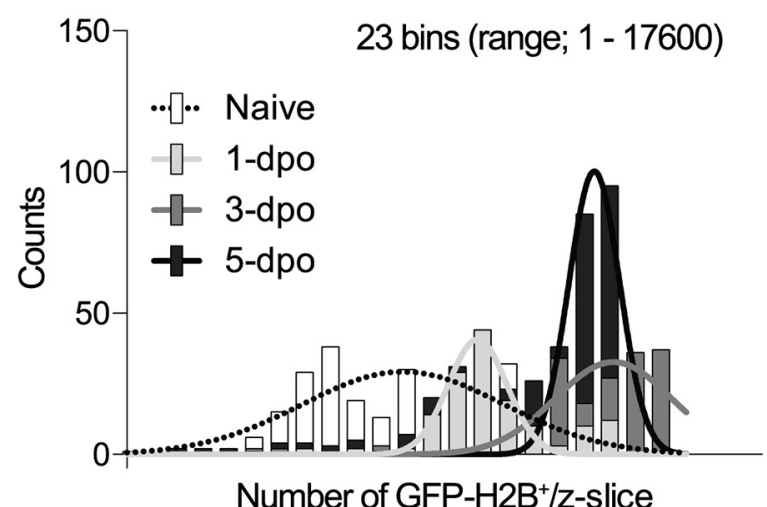

k

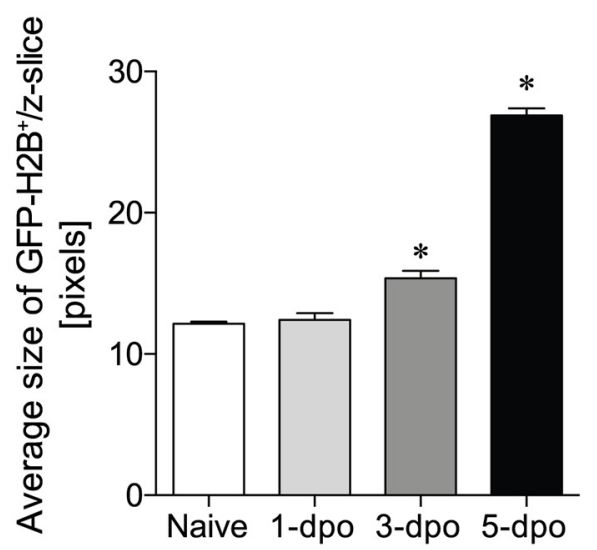

I

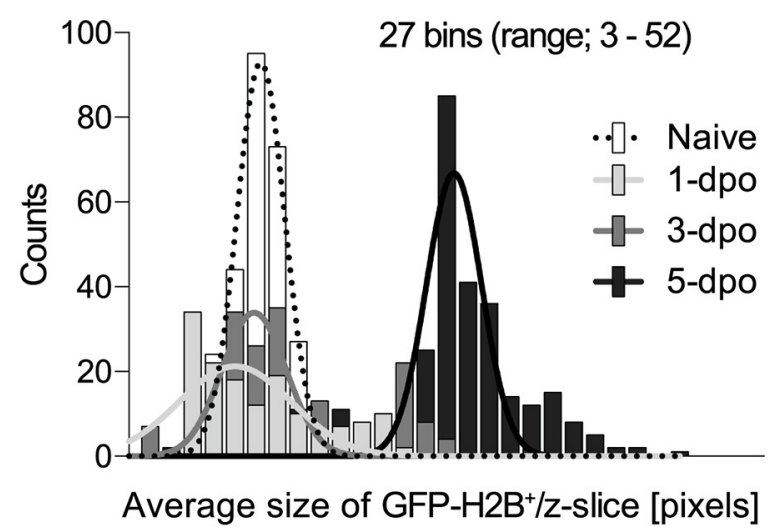

Figure 2. c-Fos activation is temporally and spatially propagated in EAE SC. $\boldsymbol{a}-\boldsymbol{h}$, Representative 3D imaging of lower (lumbar region) SCs in naive (a and $\boldsymbol{b}$ ) and EAE-induced reporter mice of 1 ( $\boldsymbol{c}$ and $\boldsymbol{d}), 3$ (e and $\boldsymbol{f}$ ), and $5(\boldsymbol{g}$ and $\boldsymbol{h})$ days post-onset (dpo, $n=2-5$ animals for each dpo). $\boldsymbol{a}, \boldsymbol{c}, \boldsymbol{e}, \boldsymbol{g}, 3 \mathrm{D}$-reconstructed images. $\boldsymbol{b}, \boldsymbol{d}, \boldsymbol{f}, \boldsymbol{h}$, Coronal sections. Scale bar, $500 \mu \mathrm{m}$. $\boldsymbol{i}$, The number of GFP-H2B ${ }^{+}$nuclei in the SCs (mean \pm SEM, $* p<0.001$ versus naive, Kruskal-Wallis test with Dunn's post hoc test, data were compiled from $273,149,185$, and 381 -slices from $3,2,2$, and 4 animals, respectively). $\boldsymbol{j}$, Distribution of the number of GFP-H2B ${ }^{+}$nuclei per $z$-slice as shown in $\boldsymbol{i}$. Lines represent Gaussian fits to the data. $\boldsymbol{k}$, Average size of GFP-H2B ${ }^{+}$signals (mean \pm SEM, $* p<0.001$ versus naive, Kruskal-Wallis test with Dunn's post hoc test, data were compiled from 273, 149, 185, and 381 z-slices from 3, 2, 2, and 4 animals, respectively). $\boldsymbol{I}$, Distribution of the average size of GFP-H2B ${ }^{+}$signals per $z$-slice shown in $\boldsymbol{k}$. Lines represent Gaussian fits to the data. 


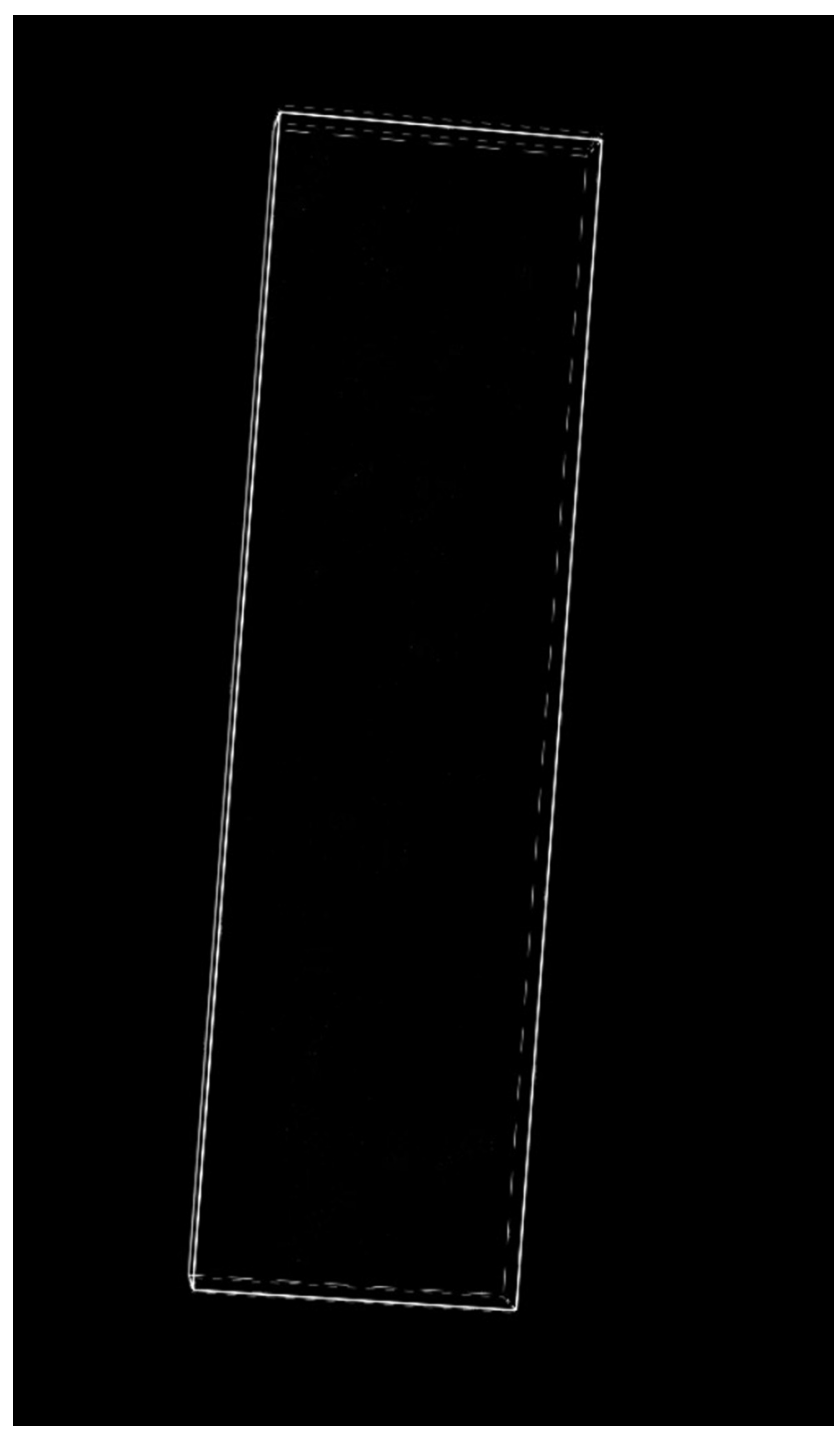

Video 1. 3D video of control spinal cord shown in Fig. 2a, b. PRINT [ View online]

0.2\% Triton X-100/20\%DMSO/0.3 M glycine. Samples were blocked in PBS containing $0.2 \%$ Triton X-100/10\% $\mathrm{DMSO} / 6 \%$ goat serum at $37^{\circ} \mathrm{C}$, washed in PBS containing $0.2 \%$ Tween 20 and $10 \mu \mathrm{g} / \mathrm{ml}$ heparin $(\mathrm{PTwH})$, and incubated in a rabbit anti-GFP antibody $(1: 1000$ dilution, MBL International Cat\# 598, RRID:AB_591819) in $\mathrm{PTwH}$ at $37^{\circ} \mathrm{C}$. Samples were washed in $\mathrm{PTwH}$, then incubated in anti-rabbit Alexa Fluor 488 (1:1000 dilution, Thermo Fisher Scientific Cat\# A-11008, RRID: AB_143165). Samples were washed again in PTwH before tissue clearing. SC samples were incubated in $50 \% \mathrm{v} / \mathrm{v}$ tetrahydrofuran $/ \mathrm{H}_{2} \mathrm{O}$ (THF, Sigma), $70 \% \mathrm{THF}$ in $\mathrm{H}_{2} \mathrm{O}, 80 \%$ THF in $\mathrm{H}_{2} \mathrm{O}, 100 \% \mathrm{THF}$, dichloromethane (Sigma), and finally dibenzyl ether (DBE). Cleared SCs were placed in a microscope chamber made with two to three stacked Fastwells (Research Products International), filled with DBE, and coverslipped. The intact SCs were imaged on a Nikon $\mathrm{A}^{+}{ }^{+}$confocal microscope using $z$-steps of $10 \mu \mathrm{m}$ under $10 \times$ objective. NISElements (v4.3, RRID:SCR_014329) was used to three-

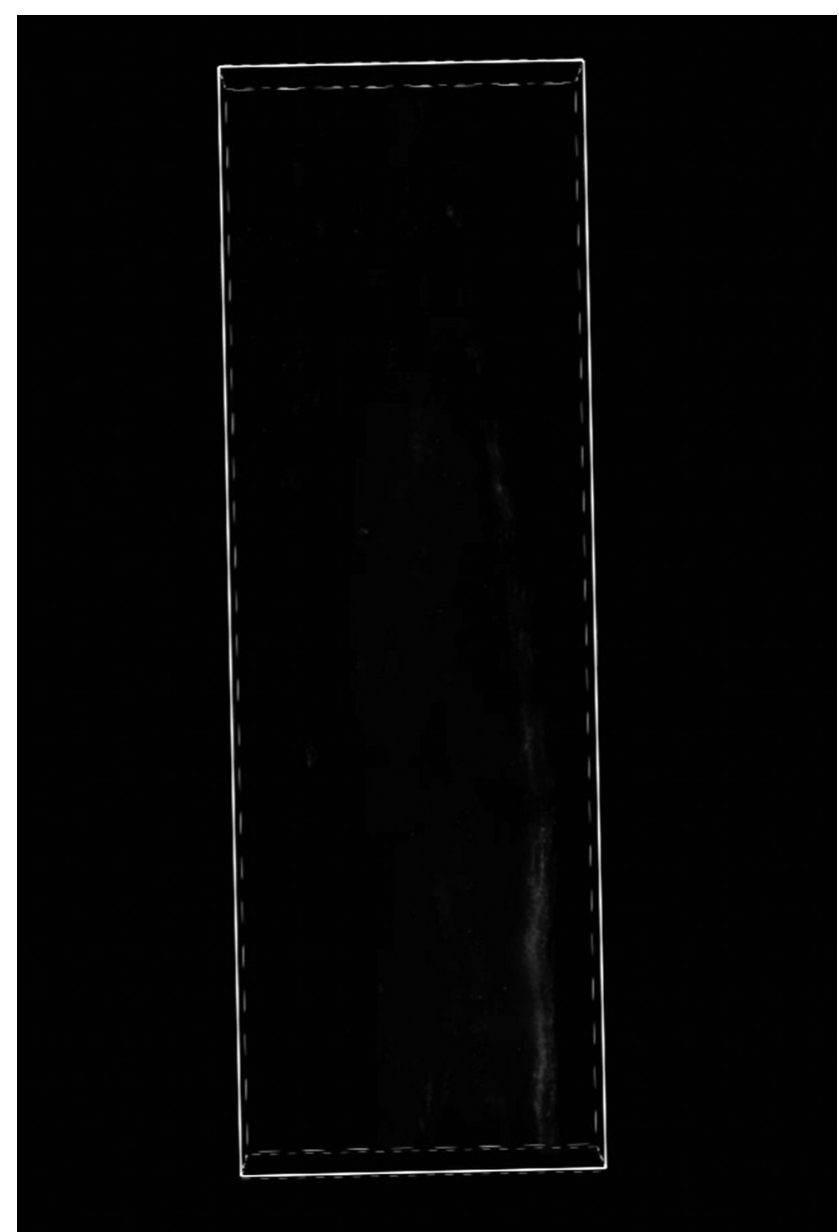

Video 2. 3D video of EAE spinal cord at 1 dpo shown in Fig. 2c, d. PRINT [ View online]

dimensionally reconstruct the entire SC. Obtained images were analyzed with ImageJ (NIH, RRID:SCR_003070) to count the number of signals, areas, and average area of signals.

\section{Flow cytometry}

SCs were rapidly dissected and frozen in liquid nitrogen. Samples were equilibrated to $4^{\circ} \mathrm{C}$ and douncehomogenized in a nucleus extraction buffer made with $0.32 \mathrm{M}$ sucrose $/ 5 \mathrm{mM} \mathrm{CaCl} / 3 \mathrm{mM} \mathrm{Mg}\left(\mathrm{CH}_{3} \mathrm{COO}\right)_{2} / 0.1 \mathrm{mM}$ EDTA/20 mM Tris- $\mathrm{HCl}$, pH 8.0/0.1\% Triton $X-100$ in DEPC-treated $\mathrm{H}_{2} \mathrm{O}$. Homogenized samples were filtered (50 $\mu \mathrm{m}$; Celltrics, Sysmex) and washed in DEPC-treated PBS containing 2 mM EDTA (PBSE-d). Nuclei were purified by centrifugation at $3250 \times \mathrm{g}$ for $12 \mathrm{~min}$ in an isosmotic iodixanol gradient made of a $35 \%, 10 \%$, and $5 \%$ OptiPrep (Sigma) in DEPC-treated $\mathrm{H}_{2} \mathrm{O}$ containing $20 \mathrm{mM}$ tricine- $\mathrm{KOH}(\mathrm{pH} 7.8), 25 \mathrm{mM} \mathrm{KCl}$, and $30 \mathrm{mM} \mathrm{MgCl} 2$ (Graham, 2001). Nuclei were recovered in the 35\%-10\% interface, washed in PBSE- $d$, and immunolabeled with rabbit anti-NeuN antibody (1:400 dilution, Millipore, Cat \#MABN140, Clone \#27-4, RRID:AB_2571567) in 1\% bovine serum albumin (BSA)/PBSE-d for $20 \mathrm{~min}$. Samples were washed in PBSE-d and labeled with a goat antirabbit APC-conjugated secondary antibody (1:500 dilu- 


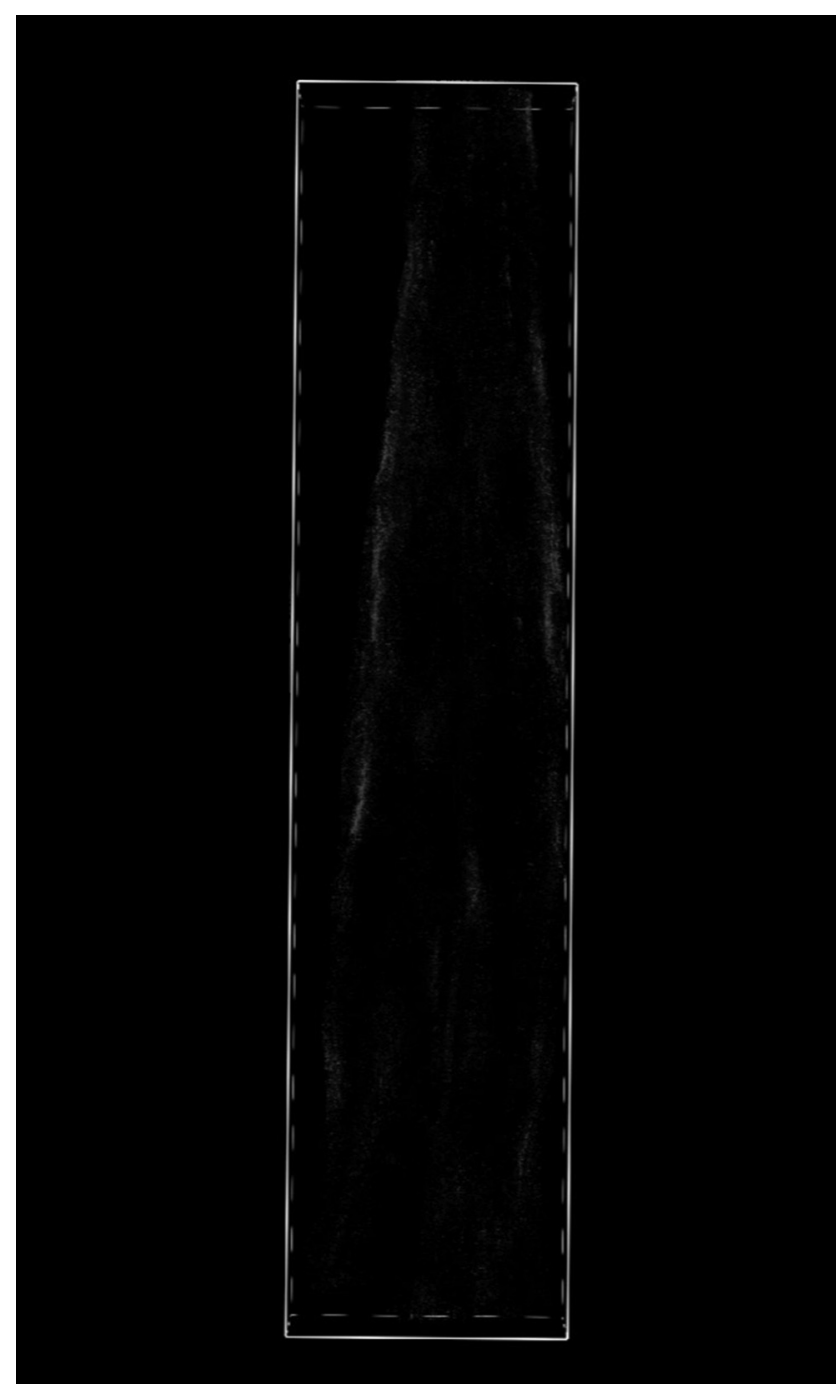

Video 3. 3D video of EAE spinal cord at 3 dpo shown in Fig. 2e, f. PRINT [ View online]

tion, Thermo Fisher Scientific, Cat\# A10931, RRID: AB 10562534) and DAPI (1:5000 dilution, Thermo Fisher Scientific, Cat\# D1306, RRID:AB_2629482) in 1\%BSA PBSE-d for $10 \mathrm{~min}$. Samples were washed in PBSE-d and suspended in PBSE-d. Nuclear populations were analyzed and sorted on a BD FACSAria II. Gating was performed as follows: (1) DAPI positive, (2) size and granularity consistent with nuclei by forward-scatter area (FSC-A) and side-scatter area (SSC-A), and (3) single nuclei selected by both FSC-A and forward-scatter height (FSC-H) and SSC-A and side-scatter height (SSC-H). Analysis was performed on FlowJo (10.0.8r1, RRID: SCR_008520).

\section{Statistical analysis}

Results are expressed as means \pm SEM. Data were analyzed statistically by means of ANOVA with indicated post hoc tests as appropriate, using GraphPad PRISM software (RRID:SCR_002798). Values of $p<0.05$ were considered to be statistically significant.

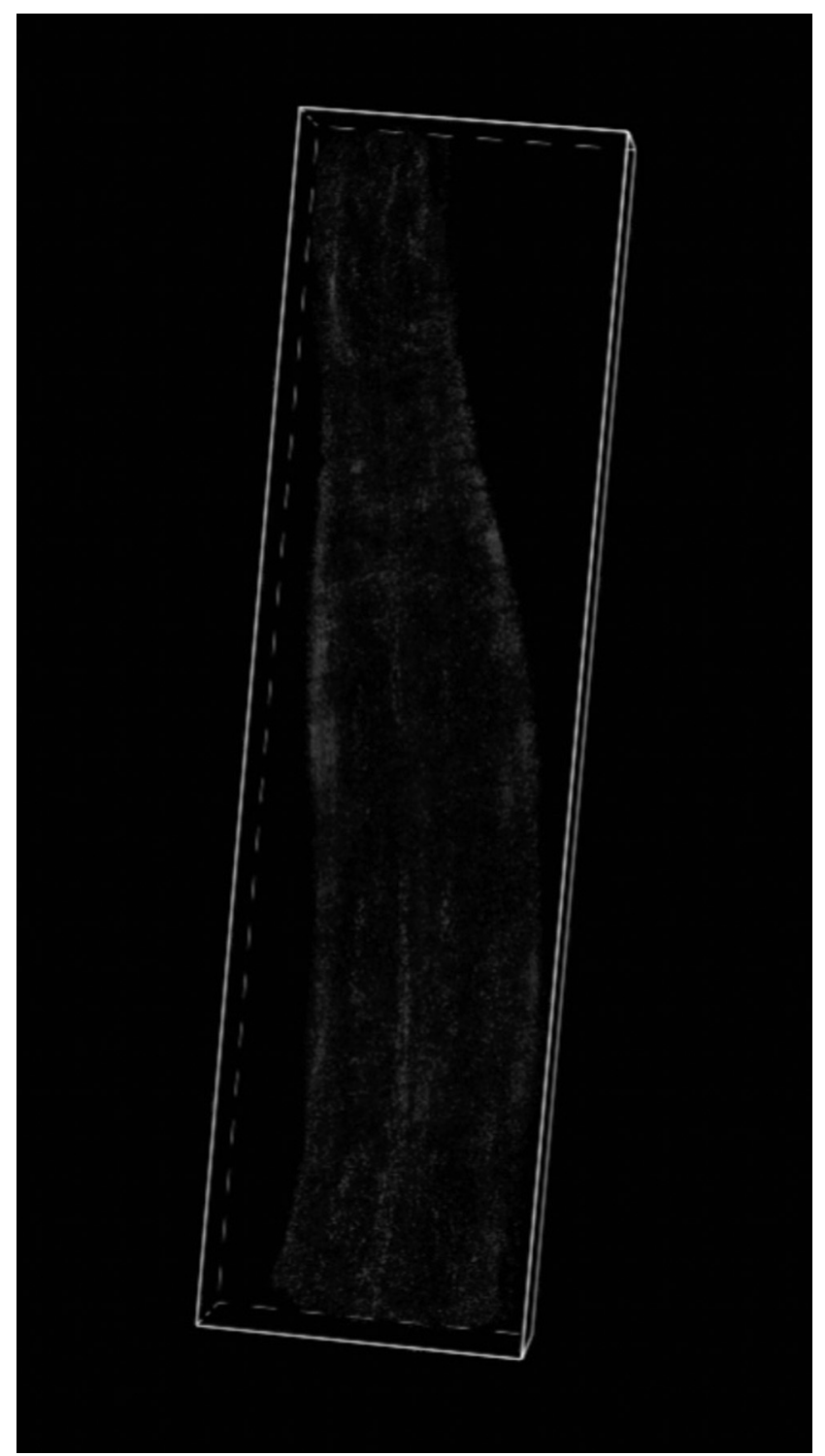

Video 4. 3D video of EAE spinal cord at 5 dpo shown in Fig. $2 g$, h. PRINT [ View online]

\section{Results}

\section{A new, in vivo c-Fos screen detects CNS cells} activated by neuroinflammation

We hypothesized that EAE would induce c-Fos expression in key, disease-relevant cells. An unbiased screen was developed using the c-Fos-inducible and doxycycline-regulated TetTag cFos system that labels cell nuclei with GFP permanently (Fig. 1a). This system was used previously to identify neurons involved in learning and memory (Matsuo et al., 2008). TetTag cFos reporter mice, immunized with $\mathrm{MOG}_{35-55}$ peptide, showed robust GFP signals in the SC $5 \mathrm{~d}$ after removal of doxycycline (Fig. 1). The increase was detected only in symptomatic EAE mice (Fig. 1c), indicating that EAE insults produced c-Fos activation in the CNS. To understand the spatio-temporal c-Fos activation pattern, EAE SCs were processed by a tissue-clearing technique, iDISCO (Renier et al., 2014), 


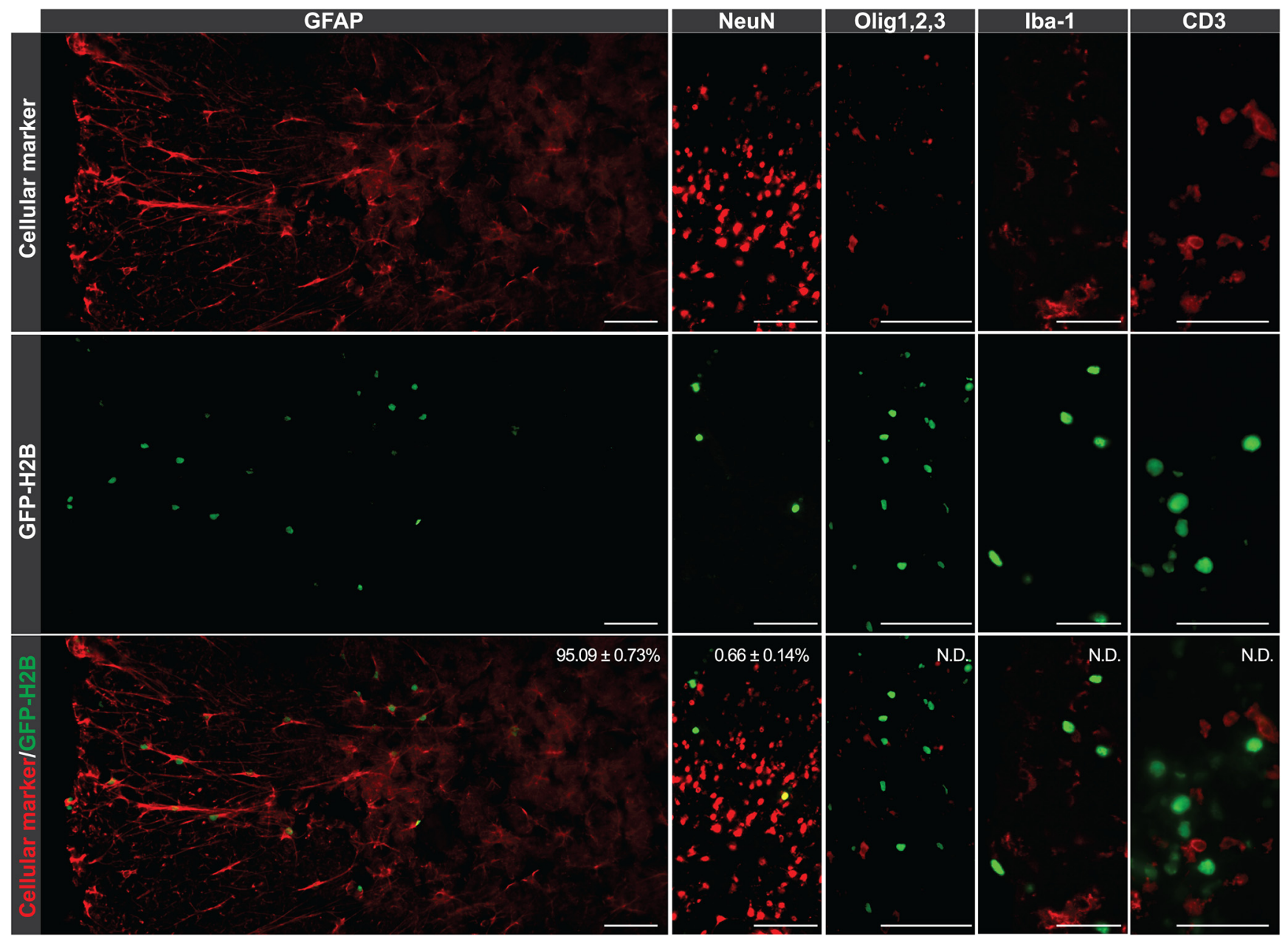

Figure 3. Immunolabeling identifies astrocytes as major c-Fos-activated cells in EAE SC. Immunolabeling for GFAP, NeuN, Olig1,2,3, Iba1, CD3, and GFP on SC sections, as indicated. Percentage overlap as indicated. N.D., not detected. $n=3$ animals. Scale bar, 100 $\mu \mathrm{m}$ (GFAP, NeuN, and Olig1,2,3) and $50 \mu \mathrm{m}$ (Iba-1 and CD3).

combined with serial confocal images (Fig. $2 a-h$; Videos 1-7). Control SC from naive mice displayed sparse GFP signals even $5 \mathrm{~d}$ after doxycycline removal (Video 1). After $1 \mathrm{~d}$ post-onset (1 dpo), $\mathrm{GFP}^{+}$nuclei appeared in the periphery of white matter tracts near associated blood vessels (Video 2). The GFP signals expanded along the rostral-caudal axis and penetrated into the white matter parenchyma over time, appearing most prominently near anatomically known major blood vessels including the anterior, posterior, and posterolateral spinal vessels (Fig. 2, Videos 3 and 4). Importantly, the number of $\mathrm{GFP}^{+}$ nuclei (Fig. $2 i, j$ ) and the average size of $\mathrm{GFP}^{+}$signals (Fig. $2 k, I)$ increased significantly over time, revealing that GFP $^{+}$nuclei aggregated to form clusters in EAE SCs at 5 dpo. These results identified robust c-Fos activation in cells near major CNS blood vessels in peripheral white matter tracts, followed by inward expansion centrally, into gray matter.

\section{c-Fos ${ }^{+}$cells are astrocytes: ieAstrocytes}

To determine the identities of $\mathrm{GFP}^{+}$cell types, immunolabeling for various cellular markers was performed on 5-dpo SC sections. Strikingly, a vast majority of GFP ${ }^{+}$ nuclei (95.09 $\pm 0.73 \%, n=3)$ were found to colabel with glial fibrillary acidic protein (GFAP; Fig. 3). By contrast, $<1 \%$ of $\mathrm{GFP}^{+}$nuclei $(0.66 \% \pm 0.14 \%, n=3)$ colocalized with a neuronal nuclear marker (NeuN). Other assessed cell types included microglia, oligodendrocytes, and $\mathrm{T}$ lymphocytes, none of which showed colocalization with GFP signals (Fig. 3), whereas $\mathrm{GFP}^{+} \mathrm{CD}^{+} \mathrm{T}$ cells were found outside of the CNS within the peripheral lymph nodes of EAE mice, demonstrating their ability to report c-Fos (data not shown). The dominance of EAE-induced $\mathrm{GFP}^{+}$astrocytes that reported transcription of the c-Fos IEG during disease development supported a functional classification for these astrocytes, which were therefore called immediate-early astrocytes (ieAstrocytes). At any given time following EAE challenge, ieAstrocytes could be distinguished from cells that did not show evidence of c-Fos activation, quiescent astrocytes (qAstrocytes).

\section{$\mathrm{S}_{1 \mathrm{P}_{1}}$ inhibition reduces formation of EAE-induced ieAstrocytes}

To test whether $\mathrm{S}_{1} \mathrm{P}_{1}$ signaling influenced formation of ieAstrocytes, we crossed astrocyte-specific $\mathrm{S}_{1} \mathrm{P}_{1}-\mathrm{KO}$ mice $\left(\mathrm{S}_{1} \mathrm{P}_{1}-\mathrm{AsCKO} ; \mathrm{S}_{1} \mathrm{P}_{1}{ }^{\text {flox/flox }}\right.$ mice harboring human 


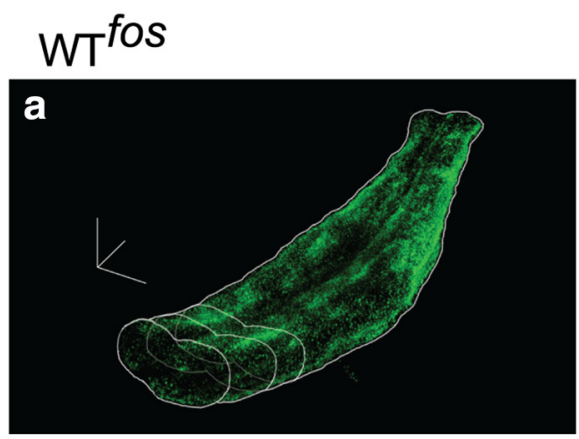

\section{$\mathrm{S}_{1} \mathrm{P}_{1} \mathrm{AsCKO}^{\text {fos }}$}
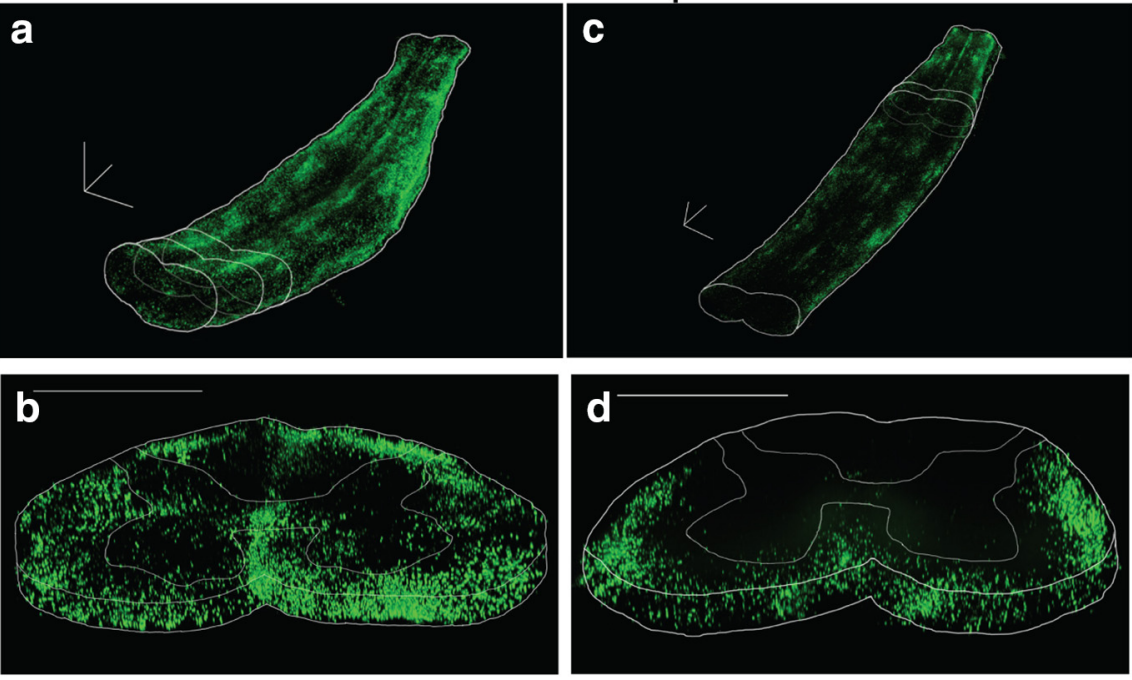

$\mathrm{WT}^{\text {fos }}+\mathrm{FTY} 720$
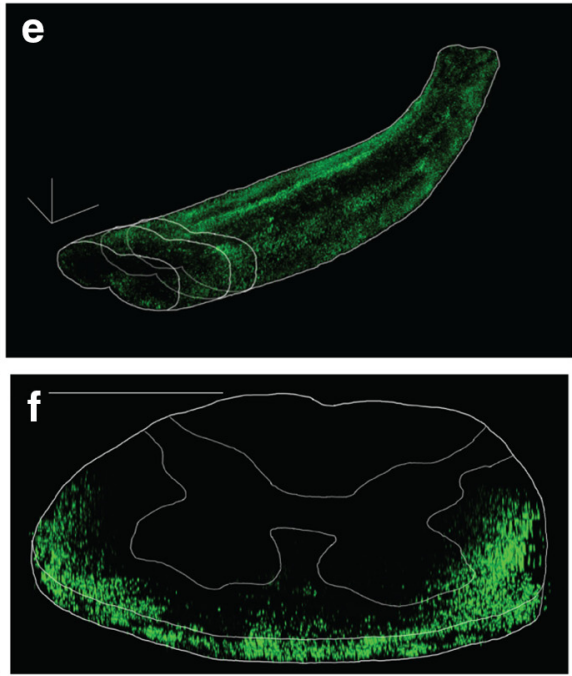

g

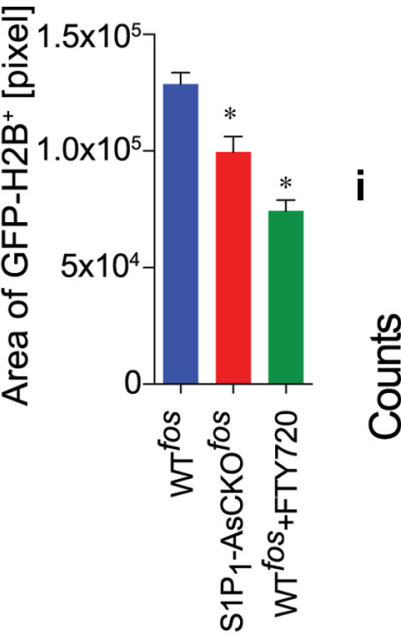

h

$\mathrm{WT}^{\text {fos }}$
${\mathrm{S} 1 \mathrm{P}_{1} \text {-AsCKO }}^{\text {fos }}$
$\mathrm{WT}^{\text {fOs }_{+}+\mathrm{FTY} 720}$

0

Average size of GFP-H2B ${ }^{+} / z-s l i c e$

[pixels]

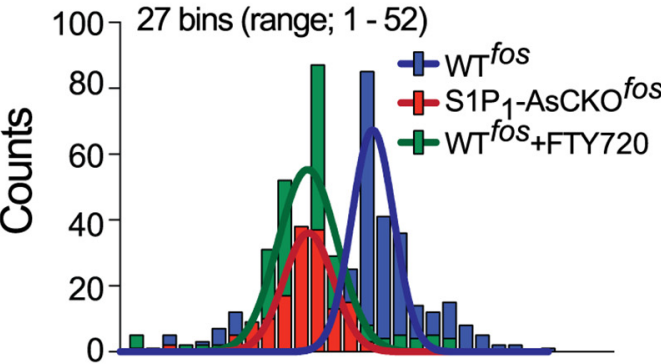

Average size of GFP-H2B ${ }^{+} / \mathrm{z}-$ slice

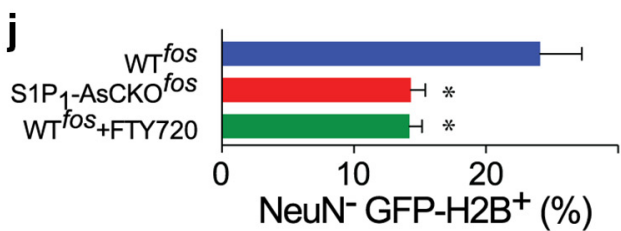

k

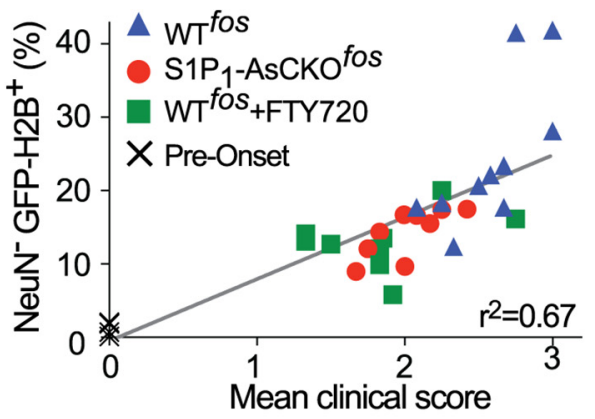

Figure 4. Genetic and pharmacological removal of $\mathrm{S}_{1} \mathrm{P}_{1}$ suppresses ieAstrocyte formation. a-f, Representative 3D imaging of lower (lumbar region) SCs in EAE-induced WT fos ( $\boldsymbol{a}$ and $\boldsymbol{b}$ ), S1P $\mathrm{S}_{1}-\mathrm{AsCKO}^{\text {fos }}$ ( $\boldsymbol{c}$ and $\boldsymbol{d}$ ), and WT ${ }^{\text {fos }}+\mathrm{FTY720}(\boldsymbol{e}$ and $\boldsymbol{f}$ ) mice of 5 dpo (dpo). $\boldsymbol{a}$, $\boldsymbol{c}, \boldsymbol{e}, 3 \mathrm{D}$-reconstructed images. $\boldsymbol{b}, \boldsymbol{d}, \boldsymbol{f}$, Coronal sections. Scale bar, $500 \mu \mathrm{m}$. $\boldsymbol{g}$, Area of GFP-H2B ${ }^{+}$signals in the spinal cords (mean \pm SEM, data were compiled from 303, 151, and 273 z-slices from $n=3,2$, and 3 animals, respectively, $* p<0.01$ versus WT ${ }^{\text {fos }}$, Kruskal-Wallis test with Dunn's post hoc test). $\boldsymbol{h}$, Average size of GFP-H2B ${ }^{+}$signals (mean $\pm \mathrm{SEM}, * p<0.001$ versus WT ${ }^{\text {fos }}$, Kruskal-Wallis test with Dunn's post hoc test, data were compiled from 303, 151, and 273 z-slices from 3, 2 , and 3 animals, respectively). $\boldsymbol{i}$, Distribution of the average size of GFP-H2B ${ }^{+}$signals per $z$-slice shown in $\boldsymbol{h}$. Lines represent Gaussian fits to the data. $\boldsymbol{j}$, ieAstrocyte $\left(\mathrm{NeuN}^{-} \mathrm{GFP}^{+}\right.$) populations in EAE SCs were determined by FCM (mean $\pm \mathrm{SEM}, n=10,9$, and 9 animals, $* p<0.05$ versus $\mathrm{WT}^{\text {fos }}$ by one-way ANOVA with Bonferroni's multiple comparisons test). $\boldsymbol{k}$, Correlation between ieAstrocyte (NeuN ${ }^{-} \mathrm{GFP}^{+}$) populations and clinical score. Each point represents a single animal.

GFAP promoter-driven Cre transgene; Choi et al., 2011) with the TetTag-c-Fos reporter mice to produce $\mathrm{S}_{1 \mathrm{P}_{1}}$ -

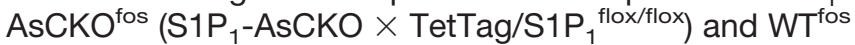
(TetTag/S1P ${ }_{1}^{\text {flox/flox }}$ ) mice, which were then challenged with EAE. For the FTY720 treatment group, FTY720 (1.0 $\mathrm{mg} / \mathrm{kg}$ ) was orally administered from defined dpo (dpo = 0 , clinical score $\geq 1.0$ ). $\mathrm{GFP}^{+}$signals at $5 \mathrm{dpo}$ in $\mathrm{S} \mathrm{P}_{1^{-}}$ $\mathrm{AsCKO}^{\text {fos }}$ and FTY720-treated $\mathrm{WT}^{\text {fos }}\left(\mathrm{WT}^{\text {fos }}+\mathrm{FTY}^{\mathrm{f}}\right.$ 20) mice were attenuated compared with WT' ${ }^{\text {fos }}$ controls (Fig. $4 a-f$ and Videos 5-7). GFP ${ }^{+}$signals were observed in gray matter of $\mathrm{WT}^{\text {fos }}$ controls (Fig. $4 b$ and Video 5), while they were rarely found in $\mathrm{S}_{1} \mathrm{P}_{1}-\mathrm{AsCKO}^{\text {fos }}$ and $\mathrm{WT}^{\text {fos }}+\mathrm{FTY} 720$ mice (Fig. 4d, $f$ and Videos 6 and 7). These were accompanied by a significant loss of ieAstrocyte numbers (Fig. $4 \mathrm{~g}$ )

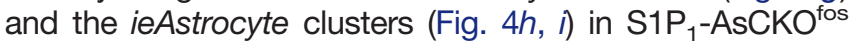
and $\mathrm{WT}^{\text {fos }}+\mathrm{FTY720}$ mice compared with $\mathrm{WT}^{\text {fos }}$ controls. 


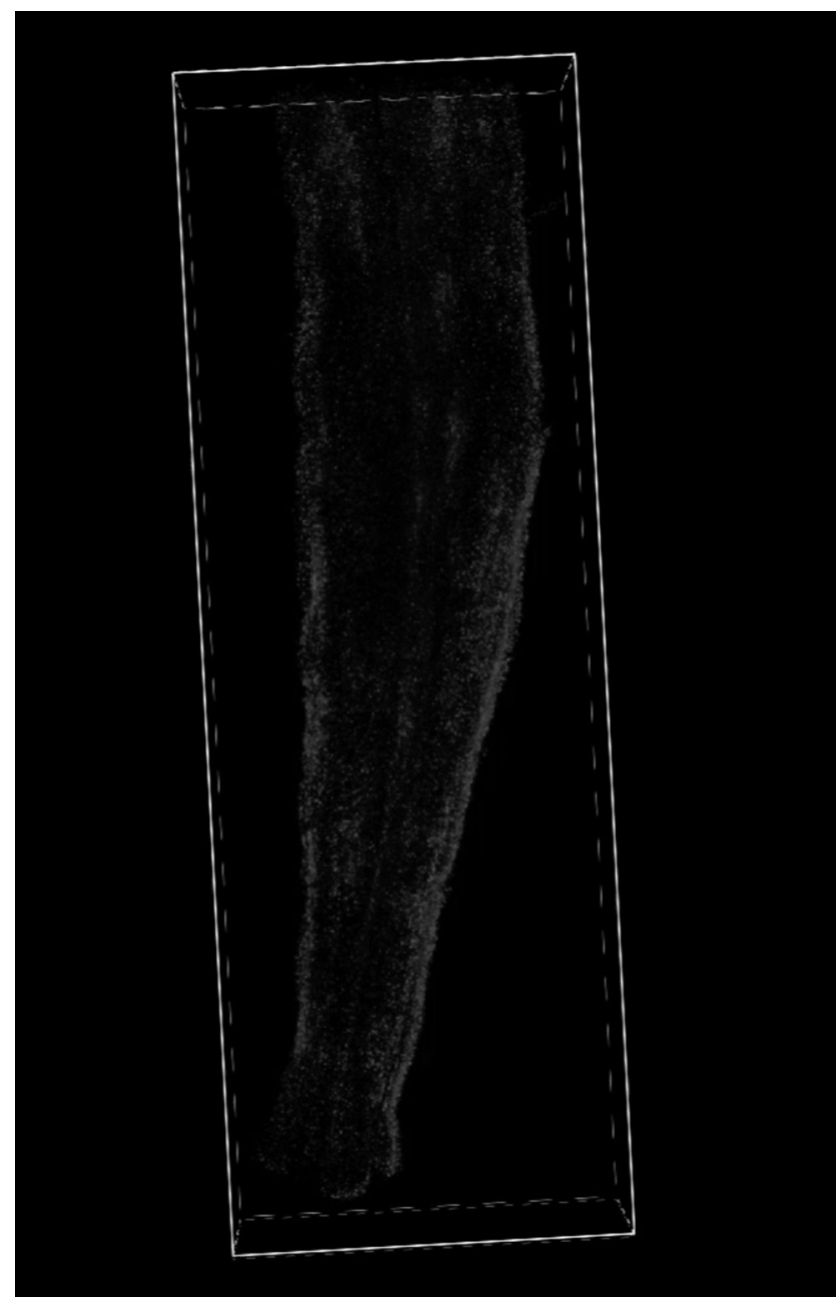

Video 5. 3D video of $W T^{\text {fos }}$ EAE spinal cord at 5 dpo shown in Fig. 4a, b. PRINT [ View online]

Flow cytometric (FCM) analysis of ieAstrocytes (DAPI-gated, $\mathrm{NeuN}^{-} \mathrm{GFP}^{+}$populations) from the SCs of EAE mice revealed a significant decrease of ieAstrocytes (Fig. 4j) and a linear correlation of increasing ieAstrocytes with worsening clinical scores (Fig. 4k). These results link ieAstrocyte formation to EAE disease progression, both of which can be modified by $\mathrm{S}_{1} \mathrm{P}_{1}$ signaling.

\section{Discussion}

The present study identified a functionally defined in vivo population of astrocytes, ieAstrocytes, as the earliest and predominant cell type responding to EAE insult. Surprisingly, other cell types were not functionally activated to a similar extent within the CNS. Moreover, ieAstrocyte formation increased with disease severity, and in part

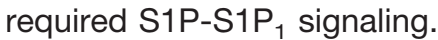

IEGs as typified by c-Fos have been used as functional markers of cellular activation (Herrera and Robertson, 1996), particularly in the nervous system, where c-Fos was used as a transynaptic marker for neuronal activity (Bullitt, 1990), and most commonly relied on immunolabeling. In the present study, we used a TetTag c-Fos reporter system that is remarkable in tracking historical

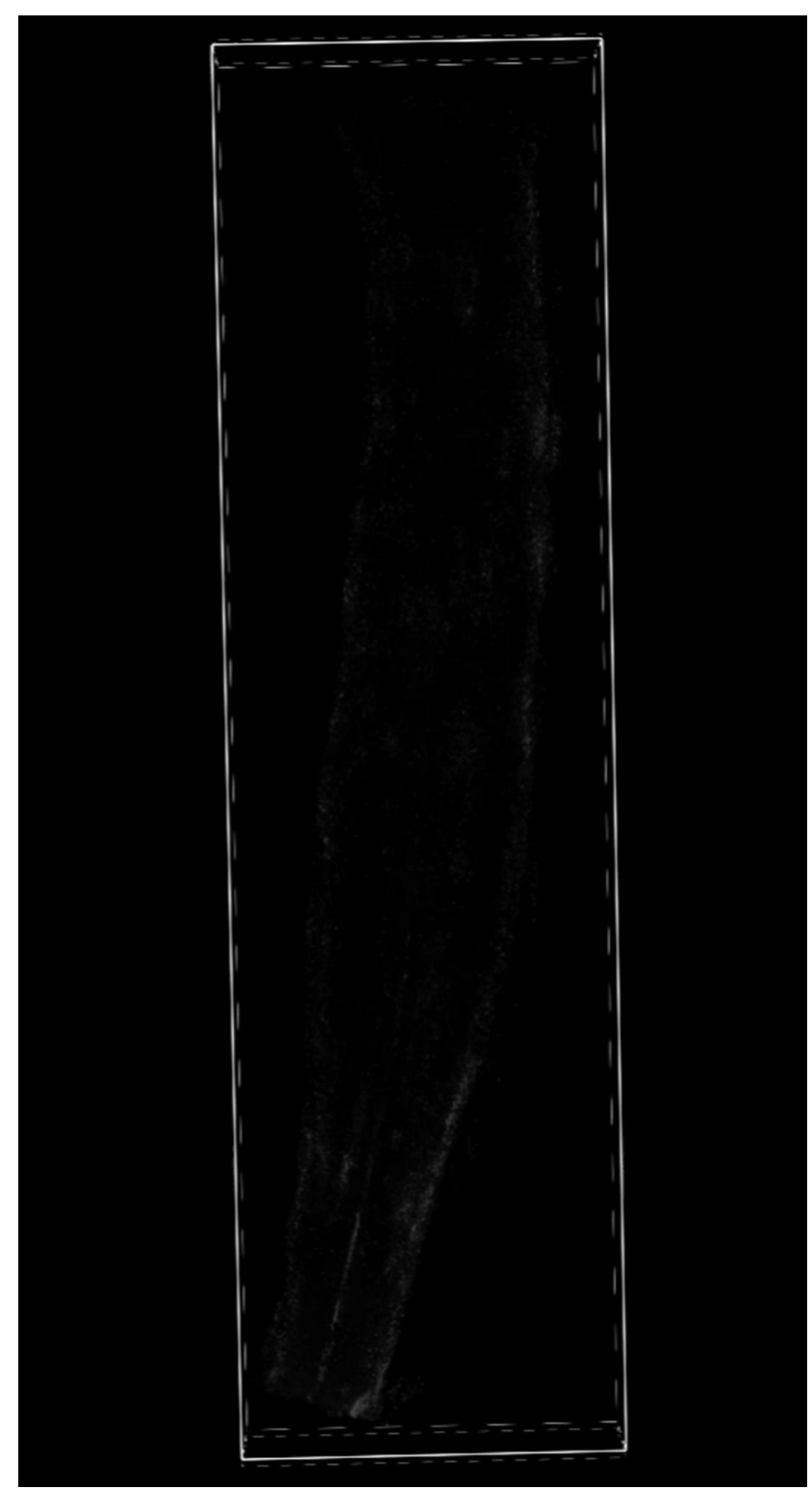

Video 6. 3D video of $\mathrm{S}_{1} \mathrm{P}_{1}-\mathrm{AsCKO}^{\text {fos }} \mathrm{EAE}$ spinal cord at $5 \mathrm{dpo}$ shown in Fig. 4c, d. PRINT [ View online]

neural activity by labeling cells with stable GFP, compared with merely capturing momentary snapshots by classical c-Fos immunolabeling. This system historically traced the cells that experienced c-Fos expression during challenges, which identified a functional subset of neurons in learning and memory (Matsuo et al., 2008; Tayler et al., 2011) and functional astrocytes in EAE (Fig. 2). Although several studies identified c-Fos immunoreactivity in neurons with exclusion of c-Fos expression in astrocytes (Staiger et al., 2002; Wang et al., 2009; Lecrux et al., 2011), it was demonstrated in cultured astrocytes stimulated with excitatory amino acids (McNaughton and Hunt, 1992) and S1P (Yester et al., 2015), as well as in in vivo astrocytes, such as in electrical sensorimotor cortex stimulation (Morishita et al., 2011) and Alzheimer's brains (Anderson et al., 1994). Moreover, results from direct activation of engineered $\mathrm{G} \alpha \mathrm{i}$-coupled GPCRs expressed 


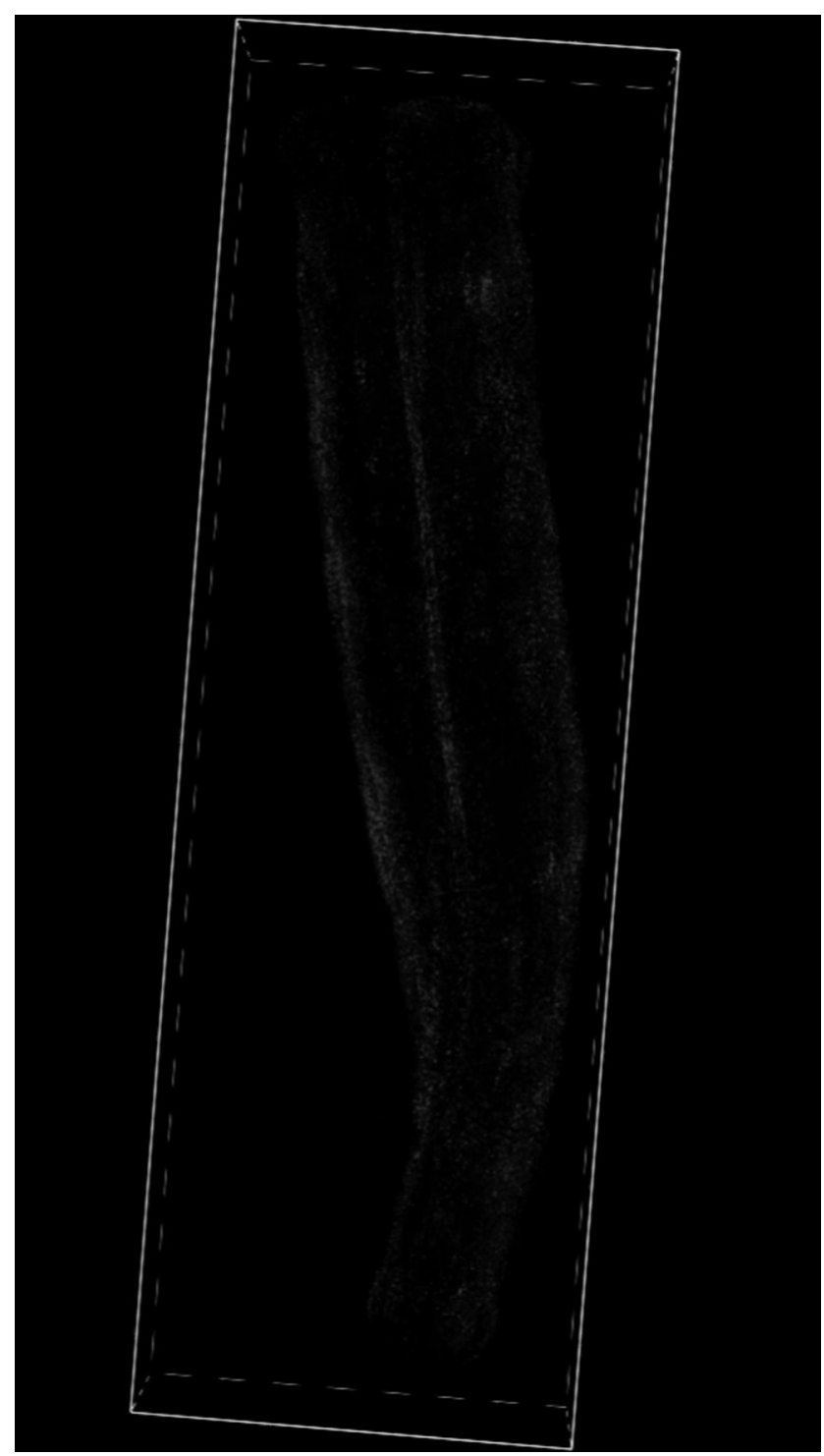

Video 7. 3D video of FTY720-treated $W T^{\text {fos }}$ EAE spinal cord at 5 dpo shown in Fig. 2e, f. PRINT [ View online]

in in vivo astrocytes using designer receptors exclusively activated by designer drugs (DREADDs; Chai et al., 2017), concur with our results that $\mathrm{G} \alpha \mathrm{i}$-coupled $\mathrm{S}_{1} \mathrm{P}_{1}$ signaling functionally activates c-Fos in astrocytes in vivo (Fig. 3).

Astrocytes are the most abundant cells in the CNS (Burda and Sofroniew, 2014; Farmer and Murai, 2017). They have been widely considered as bystanders in neuroinflammatory diseases (Rossi et al., 2007), responding secondarily under disease conditions to become reactive astrocytes that were originally defined by their hypertrophic morphology and increased GFAP expression, compared with quiescent qAstrocytes (Burda and Sofroniew, 2014; Hubbard and Binder, 2016). A recently proposed classification of $A 1$ reactive astrocytes added transcriptomic signatures to the reactive astrocyte populations (Liddelow et al., 2017). By contrast, ieAstrocytes are defined (1) functionally (via c-Fos expression) and (2) tem- porally (in vivo during EAE development and progression) (Fig. 4). Considering the nature of immediate-early and transient c-Fos expression (Herrera and Robertson, 1996), ieAstrocytes appear to differ from reactive astrocytes, possibly representing an intermediate/transition state between qAstrocytes and reactive astrocytes, which moreover is partly driven by S1P signaling (Fig. 4). A possible scenario is that during EAE development, bloodborne S1P carried by albumin and apolipoprotein $M$ (Blaho et al., 2015) at sufficient concentrations $(\sim \mu \mathrm{M})$ to activate S1P receptors (Tsai and Han, 2016) extravasates across a disrupted blood-brain barrier (Alvarez et al., 2011) to reach perivascular astrocytes in the spinal cord (Fig. 2 and Videos 1-7), resulting in direct activation of qAstrocytes to initiate ieAstrocyte formation. An alternative, but not mutually exclusive scenario, is the formation of $\mathrm{A} 1$ reactive astrocytes requiring microglial cytokine production (IL-1 $\alpha, \mathrm{TNF} \alpha$, and C1q) to activate astrocytes secondarily (Liddelow et al., 2017), to give rise to both ieAstrocytes and reactive astrocytes. The determination of the involved activation pathways will require further study.

Therapeutic reduction of $\mathrm{S}_{1} \mathrm{P}_{1}$ signaling is thought to reduce pathogenic lymphocyte trafficking into the brain, which has been proposed as the immunologic MOA of fingolimod (Mandala et al., 2002; Chun and Hartung, 2010; Arnon et al., 2011; Cohen and Chun, 2011; Chun et al., 2018). However, a direct CNS MOA involving astrocytes (Choi et al., 2011; Groves et al., 2013) receives further support through the dominant presence of ieAstrocytes, whose increasing numbers correlated with disease severity (Fig. 4k), and from the fact that genetic removal or pharmacological inhibition by fingolimod of S1P 1 signaling (Choi et al., 2011; Groves et al., 2013) reduced both ieAstrocytes and disease severity. Notably, complete $\mathrm{S}_{1} \mathrm{P}_{1}$ removal did not eliminate ieAstrocytes, indicating that other factors must be involved in their activation. In this light, other MS drugs that have been proposed to access a direct CNS MOA distinct from S1P receptor modulation in EAE, including interferon $\beta$ (Rothhammer et al., 2016) and dimethyl fumarate (Al-Jaderi and Maghazachi, 2016), might also reduce ieAstrocyte formation. Although these relationships remain to be determined, they theoretically support combination therapies that could more completely prevent ieAstrocyte formation. A next-generation S1P receptor modulator, siponi$\bmod \left(B A F 312\right.$ ), that also engages $\mathrm{S}_{1} \mathrm{P}_{1}$ (and $\mathrm{S}_{1} \mathrm{P}_{5}$ ), showed positive results in a phase III secondary progressive MS trial (Kappos et al., 2018), which is consistent with a CNS MOA involving ieAstrocytes, while other related agents like ozanimod (Cohen et al., 2016), etrasimod (Buzard et al., 2014), and ponesimod (Bolli et al., 2010; Vaclavkova et al., 2014)-having similar, albeit distinct, S1P receptor engagement properties-may also have direct CNS effects in MS through ieAstrocytes. Overall, our results support a previously unrecognized pathogenic role of functionally defined astrocytes in vivo, which could reveal new disease mechanisms and therapeutic targets accessed through ieAstrocytes. 


\section{References}

Acosta C, Anderson HD, Anderson CM (2017) Astrocyte dysfunction in Alzheimer disease. J Neurosci Res 95:2430-2447. CrossRef Medline

Al-Jaderi Z, Maghazachi AA (2016) Utilization of dimethyl fumarate and related molecules for treatment of multiple sclerosis, cancer, and other diseases. Front Immunol 7:278. CrossRef

Alvarez JI, Cayrol R, Prat A (2011) Disruption of central nervous system barriers in multiple sclerosis. Biochim Biophys Acta 1812: 252-264. CrossRef

Anderson AJ, Cummings BJ, Cotman CW (1994) Increased immunoreactivity for Jun- and Fos-related proteins in Alzheimer's disease: association with pathology. Exp Neurol 125:286-295. CrossRef

Arnon TI, Xu Y, Lo C, Pham T, An J, Coughlin S, Dorn GW, Cyster JG (2011) GRK2-dependent S1PR1 desensitization is required for lymphocytes to overcome their attraction to blood. Science 333: 1898-1903. CrossRef Medline

Blaho VA, Galvani S, Engelbrecht E, Liu C, Swendeman SL, Kono M, Proia RL, Steinman L, Han MH, Hla T (2015) HDL-bound sphingosine-1-phosphate restrains lymphopoiesis and neuroinflammation. Nature 523:342-346. CrossRef

Bolli MH, Abele S, Binkert C, Bravo R, Buchmann S, Bur D, Gatfield J, Hess P, Kohl C, Mangold C, et al . (2010) 2-Imino-thiazolidin4-one derivatives as potent, orally active S1P1 receptor agonists. J Med Chem 53:4198-4211. CrossRef Medline

Bullitt E (1990) Expression of C-fos-like protein as a marker for neuronal activity following noxious stimulation in the rat. J Comp Neur 296:517-530. CrossRef

Burda JE, Sofroniew MV (2014) Reactive gliosis and the multicellular response to CNS damage and disease. Neuron 81:229-248. CrossRef Medline

Buzard DJ, Kim SH, Lopez L, Kawasaki A, Zhu X, Moody J, Thoresen L, Calderon I, Ullman B, Han S, et al . (2014) Discovery of APD334: design of a clinical stage functional antagonist of the sphingosine1-phosphate-1 receptor. ACS Med Chem Lett 5:1313-1317. CrossRef

Cekanaviciute E, Buckwalter MS (2016) Astrocytes: integrative regulators of neuroinflammation in stroke and other neurological diseases. Neurotherapeutics 13:685-701. CrossRef

Chai H, Diaz-Castro B, Shigetomi E, Monte E, Octeau JC, Yu X, Cohn W, Rajendran PS, Vondriska TM, Whitelegge JP, et al . (2017) Neural circuit-specialized astrocytes: transcriptomic, proteomic, morphological, and functional evidence. Neuron 95:531-549.e539. CrossRef

Choi JW, Gardell SE, Herr DR, Rivera R, Lee CW, Noguchi K, Teo ST, Yung YC, Lu M, Kennedy G, et al . (2011) FTY720 (fingolimod) efficacy in an animal model of multiple sclerosis requires astrocyte sphingosine 1-phosphate receptor 1 (S1P1) modulation. Proc Natl Acad Sci USA 108:751-756. CrossRef

Chun J, Hartung HP (2010) Mechanism of action of oral fingolimod (FTY720) in multiple sclerosis. Clin Neuropharmacol 33:91-101. CrossRef Medline

Chun J, Brinkmann V (2011) A mechanistically novel, first oral therapy for multiple sclerosis: the development of fingolimod (FTY720, Gilenya). Discov Med 12:213-228.

Chun J, Kihara Y, Jonnalagadda D, Blaho VA (2018) Fingolimod: lessons learned and new opportunities for treating multiple sclerosis and other disorders. Ann Rev Pharmacol Toxicol, in press.

Cohen JA, Chun J (2011) Mechanisms of fingolimod's efficacy and adverse effects in multiple sclerosis. Ann Neurol 69:759-777. CrossRef Medline

Cohen JA, Arnold DL, Comi G, Bar-Or A, Gujrathi S, Hartung JP, Cravets M, Olson A, Frohna PA, Selmaj KW, et al . (2016) Safety and efficacy of the selective sphingosine 1-phosphate receptor modulator ozanimod in relapsing multiple sclerosis (RADIANCE): a randomised, placebo-controlled, phase 2 trial. Lancet Neurol 15: 373-381. CrossRef
Colombo E, Di Dario M, Capitolo E, Chaabane L, Newcombe J, Martino G, Farina C (2014) Fingolimod may support neuroprotection via blockade of astrocyte nitric oxide. Ann Neurol 76:325-337. CrossRef Medline

Dusaban SS, Chun J, Rosen H, Purcell NH, Brown JH (2017) Sphingosine 1-phosphate receptor 3 and RhoA signaling mediate inflammatory gene expression in astrocytes. J Neuroinflammation 14:111. CrossRef

Eun SY, Hong YH, Kim EH, Jeon H, Suh YH, Lee JE, Jo C, Jo SA, Kim $J$ (2004) Glutamate receptor-mediated regulation of c-fos expression in cultured microglia. Biochem Biophys Res Commun 325: 320-327. CrossRef

Farmer WT, Murai K (2017) Resolving astrocyte heterogeneity in the CNS. Front Cell Neurosci 11:300. CrossRef Medline

Gardell SE, Dubin AE, Chun J (2006) Emerging medicinal roles for lysophospholipid signaling. Trends Mol Med 12:65-75. CrossRef Medline

González H, Pacheco R (2014) T-cell-mediated regulation of neuroinflammation involved in neurodegenerative diseases. J Neuroinflammation 11:201. CrossRef

Graham JM (2001). Isolation of nuclei and nuclear membranes from animal tissues. In Current Protocols in Cell Biology. Hoboken, NJ: Wiley.

Groves A, Kihara Y, Chun J (2013) Fingolimod: direct CNS effects of sphingosine 1-phosphate $(\mathrm{S} 1 \mathrm{P})$ receptor modulation and implications in multiple sclerosis therapy. J Neurol Sci 328:9-18. CrossRef

Herr DR, Chun J (2007) Effects of LPA and S1P on the nervous system and implications for their involvement in disease. Curr Drug Targets 8:155-167. Medline

Herrera DG, Robertson HA (1996) Activation of c-fos in the brain. Prog Neurobiol 50:83-107. Medline

Hubbard AJ, Binder DK (2016). Chapter 1. History of astrocytes. In Astrocytes and Epilepsy. Cambridge, MA: Academic Press, pp. 138.

Kappos L, Bar-Or A, Cree BAC, Fox RJ, Giovannoni G, Gold R, Vermersch P, Arnold DL, Arnould S, Scherz T, et al . (2018) Siponimod versus placebo in secondary progressive multiple sclerosis (EXPAND): a double-blind, randomised, phase 3 study. Lancet 391:1263-1273. CrossRef

Kihara Y, Matsushita T, Kita Y, Uematsu S, Akira S, Kira J-i, Ishii S, Shimizu T (2009) Targeted lipidomics reveals mPGES-1-PGE2 as a therapeutic target for multiple sclerosis. Proc Natl Acad Sci USA 106:21807-21812. CrossRef

Kihara Y, Maceyka M, Spiegel S, Chun J (2014) Lysophospholipid receptor nomenclature review: IUPHAR Review 8 . Br J Pharmacol 171:3575-3594. CrossRef

Kihara Y, Mizuno H, Chun J (2015) Lysophospholipid receptors in drug discovery. Exp Cell Res 333:171-177. CrossRef Medline

Lau LF, Nathans D (1987) Expression of a set of growth-related immediate early genes in BALB/c 3 T3 cells: coordinate regulation with c-fos or c-myc. Proc Natl Acad Sci USA 84:1182-1186. Medline

Lecrux C, Toussay X, Kocharyan A, Fernandes P, Neupane S, Levesque M, Plaisier F, Shmuel A, Cauli B, Hamel E (2011) Pyramidal neurons are "neurogenic hubs" in the neurovascular coupling response to whisker stimulation. J Neurosci 31:9836-9847. CrossRef

Lee CW, Choi JW, Chun J (2010) Neurological S1P signaling as an emerging mechanism of action of oral FTY720 (fingolimod) in multiple sclerosis. Arch Pharm Res 33:1567-1574. CrossRef Medline

Liddelow SA, Guttenplan KA, Clarke LE, Bennett FC, Bohlen CJ, Schirmer L, Bennett ML, Münch AE, Chung WS, Peterson TC, et al. (2017) Neurotoxic reactive astrocytes are induced by activated microglia. Nature 541:481-487. CrossRef

Mandala S, Hajdu R, Bergstrom J, Quackenbush E, Xie J, Milligan J, Thornton R, Shei GJ, Card D, Keohane C, et al . (2002) Alteration of lymphocyte trafficking by sphingosine-1-phosphate receptor agonists. Science 296:346-349. CrossRef 
Matsuo N, Reijmers L, Mayford M (2008) Spine-type-specific recruitment of newly synthesized AMPA receptors with learning. Science 319:1104-1107. CrossRef Medline

McNaughton LA, Hunt SP (1992) Regulation of gene expression in astrocytes by excitatory amino acids. Brain Res Mol Brain Res 16:261-266. Medline

Moon E, Han JE, Jeon S, Ryu JH, Choi JW, Chun J (2015) Exogenous $\mathrm{S} 1 \mathrm{P}$ exposure potentiates ischemic stroke damage that is reduced possibly by inhibiting S1P receptor signaling. Mediators Inflamm 2015:492659. CrossRef

Morishita T, Yamashita A, Katayama Y, Oshima H, Nishizaki Y, Shijo K, Fukaya C, Yamamoto T (2011) Chronological changes in astrocytes induced by chronic electrical sensorimotor cortex stimulation in rats. Neurol Med Chir (Tokyo) 51:496-502. CrossRef

Muir DA, Compston DA (1996) Growth factor stimulation triggers apoptotic cell death in mature oligodendrocytes. J Neurosci Res 44:1-11. CrossRef

Mullershausen F, Craveiro LM, Shin Y, Cortes-Cros M, Bassilana F, Osinde M, Wishart WL, Guerini D, Thallmair M, Schwab ME, Sivasankaran R, Seuwen K, Dev KK (2007) Phosphorylated FTY720 promotes astrocyte migration through sphingosine-1phosphate receptors. J Neurochem 102:1151-1161. CrossRef

Noguchi K, Chun J (2011) Roles for lysophospholipid S1P receptors in multiple sclerosis. Crit Rev Biochem Mol Biol 46:2-10. CrossRef

Noseworthy JH, Lucchinetti C, Rodriguez M, Weinshenker BG (2000) Multiple sclerosis. N Engl J Med 343:938-952. CrossRef Medline

Proia RL, Hla T (2015) Emerging biology of sphingosine-1-phosphate: its role in pathogenesis and therapy. J Clin Invest 125: 1379-1387. CrossRef Medline

Renier N, Wu Z, Simon DJ, Yang J, Ariel P, Tessier-Lavigne M (2014) iDISCO: a simple, rapid method to immunolabel large tissue samples for volume imaging. Cell 159:896-910. CrossRef

Rossi DJ, Brady JD, Mohr C (2007) Astrocyte metabolism and signaling during brain ischemia. Nat Neurosci 10:1377-1386. CrossRef
Rothhammer V, Mascanfroni ID, Bunse L, Takenaka MC, Kenison JE, Mayo L, Chao CC, Patel B, Yan R, Blain M, et al . (2016) Type I interferons and microbial metabolites of tryptophan modulate astrocyte activity and central nervous system inflammation via the aryl hydrocarbon receptor. Nat Med 22:586-597. CrossRef

Rouach N, Pébay A, Même W, Cordier J, Ezan P, Etienne E, Giaume C, Tencé M (2006) S1P inhibits gap junctions in astrocytes: involvement of $\mathrm{G}$ and Rho GTPase/ROCK. Eur J Neurosci 23:14531464. CrossRef Medline

Staiger JF, Masanneck C, Bisler S, Schleicher A, Zuschratter W, Zilles K (2002) Excitatory and inhibitory neurons express c-Fos in barrel-related columns after exploration of a novel environment. Neuroscience 109:687-699. CrossRef

Tayler K, Lowry E, Tanaka K, Levy B, Reijmers L, Mayford M, Wiltgen B (2011) Characterization of NMDAR-independent learning in the hippocampus. Front Behav Neurosci 5:CrossRef

Trépanier MO, Hopperton KE, Mizrahi R, Mechawar N, Bazinet RP (2016) Postmortem evidence of cerebral inflammation in schizophrenia: a systematic review. Mol Psychiatry 21:1009-1026. CrossRef Medline

Tsai HC, Han MH (2016) Sphingosine-1-phosphate (S1P) and S1P signaling pathway: therapeutic targets in autoimmunity and inflammation. Drugs 76:1067-1079. CrossRef

Vaclavkova A, Chimenti S, Arenberger P, Holló P, Sator PG, Burcklen M, Stefani M, D'Ambrosio D (2014) Oral ponesimod in patients with chronic plaque psoriasis: a randomised, double-blind, placebo-controlled phase 2 trial. Lancet 384:2036-2045. CrossRef

Wang W, Wang W, Mei X, Huang J, Wei Y, Wang Y, Wu S, Li Y (2009) Crosstalk between spinal astrocytes and neurons in nerve injuryinduced neuropathic pain. PLoS One 4:e6973. CrossRef

Yester JW, Bryan L, Waters MR, Mierzenski B, Biswas DD, Gupta AS, Bhardwaj R, Surace MJ, Eltit JM, Milstien S, et al . (2015) Sphingosine-1-phosphate inhibits IL-1-induced expression of C-C motif ligand 5 via C-Fos-dependent suppression of IFN-beta amplification loop. FASEB J 29:4853-4865. CrossRef 